\title{
Streams' and Springs' Biophysical Dynamics as Structuring Elements of Future Urban Development: Systemic Strategies for Spatial Planning - A Case Study in Uberlândia, MG, Brazil
}

Julia Figueiredo-Cunha ( $\sim$ juliafigueiredoo@gmail.com )

Federal University of Rio de Janeiro: Universidade Federal do Rio de Janeiro https://orcid.org/0000-0002-4606-0311

Raquel Tardin-Coelho

Universidade Federal do Rio de Janeiro

\section{Research Article}

Keywords: streams, springs, biophysical dynamics, spatial planning strategies, urban development

Posted Date: December 6th, 2021

DOl: https://doi.org/10.21203/rs.3.rs-1111625/v1

License: (a) (i) This work is licensed under a Creative Commons Attribution 4.0 International License. Read Full License 


\section{Abstract}

Historically, water bodies were gradually conditioned by unsustainable spatial planning practices, which led to conflicting and fragmented relationships between urban development and water dynamics. Streams and springs are more vulnerable to urban interventions and less identified as protagonists of urban structuring than rivers. However, they present the potential to guide urban development regarding their broad capillarity, easy manipulation and close relationship with urban fabrics, especially in developing country fast-urbanisation reality. Also, there is a demand for more holistic and practical approaches regarding water dynamics and urban development alternatives that can add value to water-centred initiatives focused on water management. This article proposes a methodological framework focused on formulating systemic spatial planning strategies (land-use and urban design guidelines) based on streams' and springs' spatially and functionally biophysical dynamics as structuring elements of future urban development towards composing one urban-eco system. The following principles guide the planning strategies: a) to guarantee water dynamics whole functioning as constraints to urban land-use definition; $b$ ) to promote potential functional and spatial integration between the urban fabric and water bodies that guide the configuration of urban fabrics according to the whole functioning of water dynamics. The spatial planning strategies show the potential to be systematically applied throughout a city, systemically addressing and integrating water dynamics and urban development issues towards a more sustainable and resilient reality, on a broader scale perspective and not only on-site symptoms.

\section{Introduction}

Historically, the development of urban environments sought the proximity to water bodies as an essential asset, which denotes the historical importance of water closeness for different cities worldwide (Spirn 1984; Hough 1995; Riley 1998). Urban development based on water control through engineering (e.g., dams, channels, and concrete pipes ) gradually resulted in progressive conditioning of the water dynamics and its consequent deterioration, both from spatially and functionally perspectives (Hough 1995). This development model, usually sustained by inappropriate spatial planning regulations, proved unsustainable over time, causing a series of risks to human life (e.g., flooding, drought, landslides, among others) and evidencing a conflicting interface between urban development and water dynamics (Spirn 1984; Philip 2011; Childers 2015; Liao et al. 2016).

It is possible to identify that streams and springs are more vulnerable to interventions during cities' development due to their scale and broad penetration in the territory, easily manipulated, having their courses often modified or grounded (Riley 1998). Such manipulation may compromise the water flow to the entire watershed since they are a starting point that feeds the whole basin from a water and biological perspective (Meyer et al. 2003; Wipfli et al. 2007).

The adverse effects of urbanisation on streams are known as the urban stream syndrome (Walsh et al. 2005). This phenomenon represents the degradation process of streams in urbanised catchment areas caused by different stressors, such as catchment imperviousness, sanitary sewer overflow, stormwater runoff, and wastewater treatment effluents (Walsh et al. 2005).

Water ecosystems inside urban areas, including streams, are responsible for a series of ecosystem services with impact on environmental, social and economic issues, such as flood control, soil erosion control, water quality regulation, water storage provision, urban water biodiversity, recreation opportunities, and cultural linkages (Arthington et al. 2010; Yaacovi et al. 2021). The fully functioning of these ecosystems is fundamental for climate adaptation and urban resilience facing climate change (Liao 2014).

This fact indicates the urgency to take streams' and springs' biophysical dynamics as structuring elements of future urban development. Also, it is important to consider them as a whole regarding the basin scale and a fundamental part of the city. Streams and springs are alive elements and not passive assets subjugated to urban development needs. Promoting the interface between water dynamics functioning, urban development goals, and spatial planning regulations (environmental and urban ones) is vital to ensuring that future urban development will be possible based on the systemic springs' and streams' functioning.

To this end, this article proposes ecosystems and the built environment be planned intertwined, forming one urban-eco system whose open spaces and their biophysical attributes constitute the built environment backbone, structuring urban development, especially in an irrigated territory (Tardin 2013). In this situation, the water is not only assimilated into the urban development but it is a primary driver of its construction being systemically integrated with it through functional and spatial interrelations (Tardin 2013). Water dynamics and urban development can be conceived through spatial planning strategies based on alternative urban interventions that consider water dynamics a driver of land-use and urban design guidelines (Liao et al. 2016; Miguez et al. 2019). This facilitates risk

Page $2 / 40$ 
management (Barbedo et al. 2014), improves urban resilience (Liao 2012), avoids costly damages, and becomes part of local people's lives (Wantzen et al. 2019).

Different approaches to water dynamics and urban development have shown the importance of spatially and functionally incorporating those dynamics in future urbanisation, mainly through non-structural measures, when possible (Liao 2016), contrasting to the broad application of engineering structural measures. Some authors indicate that the earlier it happens, the better (Benedict and McMahon 2006; Carmon and Shamir 2010) since it is more likely to keep the water dynamics functions and the spaces needed for their performance while guiding future urbanisation.

Approaches such as green infrastructure (Benedict and McMahon 2006; Kloss and Calarusse 2006; Luc 2009), blue-green infrastructure (Benedict and McMahon 2006; Ramboll 2016; Drosou et al. 2019), Water Sensitive Urban Design (Wong 2006; Langenbach et al. 2008; Philip 2011), Low Impact Development (Martin-Mikle et al. 2015); Sustainable Urban Drainage Systems (Woods-Ballard et al. 2015), provide alternatives for urban interventions where water dynamics guide urban planning and design proposals. Those alternatives are based on urban drainage solutions focusing on flood management, water quality improvement, and aquatic ecosystem protection (Fletcher et al. 2015).

However, more holistic and practical approaches towards water dynamics' functioning and urban development alternatives are needed focused on site knowledge and scalable solution strategies (Palazzo 2019). This issue is even more dramatic when considering the urban streams' realities, as those are much less treated in the current literature than rivers. On the other hand, it is worth highlighting that this need is still more urgent in developing countries' cities under a fast urbanisation process regulated by abstract and segmented environmental and urban regulations (Wenger et al. 2009; Wantzen et al. 2019).

This paper addresses both gaps by highlighting a practical and systemic approach towards water dynamics, urban development and spatial planning broadly implemented to transform the future urban reality of developing countries' cities into more sustainable and resilient ones, mainly those with a significant amount of open spaces expecting future urban development.

Uberabinha River's tributaries in the city of Uberlândia, Minas Gerais, Brazil, are presented as a case study. The city was formed and developed along and beyond Uberabinha River's watershed slopes, permeated by a rich capillary web of numerous tributaries. Uberlândia is an intermediate city in Brazil's interior in an accelerated urban expansion process, with a population growth rate of $20.5 \%$ between 2000 and 2010 (PMU 2017), counting with large open spaces for future urbanisation.

In this context, this research aims to develop a methodological framework for proposing systemic spatial planning strategies based on streams' and springs' biophysical dynamics as structuring elements of future urban development. Those strategies encompass landuse and urban design guidelines for future urban development that assure open spaces to accommodate the water dynamics, integrate water bodies' functional and spatial dynamics, and are driven by them. If adopted systematically, those strategies may positively reflect on a broader scale toward urban and biophysical regeneration by acting on the watershed catchment area and not only on-site symptoms.

\section{Methodology}

The methodological framework circumscribes:

1) Case study problematisation according to the following parameters:

a. Biophysical system. It considers hydrography, vegetation, climate, soils, topography attributes and related inter-relationships, highlighting the importance of streams and springs maintenance as part of the whole basin.

b. Urban system. It identifies the existing built-up areas and their territorial situation; water bodies insertion within the urban fabric; common relationships between water bodies and the structuring of urban fabrics; urban sprawl vectors; and possible future urban fabrics locations.

c. Planning rules. It recognises the current urban and environmental legislation affecting water dynamics' protection and the future urban development construction.

b) Analysis of existing built-up areas, which follow the current planning rules, and their relationship with streams and springs to find interface patterns between both. The intention is to see how the planning rules influence the existing built-up area design and its 
relationships with streams and springs, pointing out problems and potentialities concerning stream and spring full functioning and as potential urban fabric structuring elements.

This analysis is based on the following:

a) Urban fabric. The analysis focuses on:

i. functional attributes - mono or multifunctional; conflicting uses regarding water bodies; the presence of urban drainage, water supply, and sewage systems; existing public open spaces, main social activities related to water, and public access to streams and springs' banks and water -;

ii. spatial attributes - opened or closed allotments (e.g., counting with the presence of gates or fences); water continuity inside the urban fabric; buildings, lots and street design patterns and their relationship with the water bodies and their dynamics (e.g., direct contact with the water, soil permeability, floodplain provision, etc.).

The objective is to observe if the current urban fabric incorporates the water dynamics and if the water dynamics contribute (or not) to functional and spatial interrelations among the urban fabric components - buildings/lots, urban open spaces, and local roadway infrastructure - and the water itself.

b) Streams and springs. The observation of the relationship between the urban fabrics, streams and springs, and water dynamics' spatial and functional needs to occur, paying attention to the water connection with the vegetation, topography, soils, and other surrounding spaces, and the possible structuring of the urban fabric by the water dynamics.

c) Planning rules. The understanding of existing water protection and urban development regulations and how they condition the interface patterns between built-up areas and streams and springs, considering:

i. constraints to urban development according to water dynamics' spatial and functional needs;

ii. definition of land-use and activities and the spatial design.

The proposal is to observe how the planning rules allow for the water dynamics to occur, spatially and functionally, and create problems and potentialities for streams and springs to act as potential structuring elements of future urban development. The problems and potentialities found indicate guidelines for a subsequent proposal of systemic spatial planning strategies.

3) Proposal of systemic spatial planning strategies (land-use and urban design guidelines). The objective is to propose systemic spatial planning strategies based on spatial and functional principles to present alternative urban-eco system patterns structured by streams' and springs' water dynamics. Two interfaces are considered, following functional and spatial relationships in a synergic perspective (Tardin 2013):

Water $\mathrm{x}$ water - it aims to guarantee water dynamics whole functioning and define constraints to urban land-use, according to the necessity of space reservation to accommodate such dynamics; as a result, it guides the definition of spaces that can be occupied or not by urban development;

Water $\mathrm{x}$ urban fabric - it aims to promote potential functional and spatial integration between the urban fabric and water bodies and ensure the configuration of urban fabrics according to the whole functioning of water dynamics.

a) Interface water $x$ water functional and spatial relationships:

i. Spatial principle - Continuity: implies ensuring the necessary spaces to accommodate water dynamics - in a rainy or dry season

- in order to allow its passage and overflow that should not be interrupted, strangled, or channelled. Maintaining physical continuity and connections between the stream channel and surrounding floodplains and springs is fundamental (Meyer et al. 2003; Lowe and Likens 2005). Otherwise, it can threaten the flow of the entire watershed (Liao 2012);

ii. Functional principle - Fluidity: implies ensuring water's flow and movement, which must be preserved and favoured for the desired functional connections effective maintenance, to allow all ecosystemic services. The fluidity may be related to the water's path, the needed exchanges between different parts of the watercourse - upstream and downstream -, and the water cycle stages precipitation, surface runoff, infiltration, evaporation/evapotranspiration, among others. The exchange of organic matter and energy between the stream's channel, its banks, riparian vegetation, soil, groundwater, upstream and downstream, allows the desired development of all ecosystemic processes (Meyer et al. 2003; Wipfli et al. 2007).

Page 4/40 
b) Interface water $x$ urban fabric functional and spatial relationships:

i. Spatial principle - Adaptation: contemplates the assimilation of water's dynamics as a guide for the spatial definition to allocate future urban fabrics to guarantee the maintenance of water bodies' functional connections (Wipfli et al. 2007). For this, it is crucial to consider the essential links with floodplains (Liao 2012) and water's flow natural axes conformed by topography (WoodsBallard et al. 2015) to spatially guarantee a wide accommodation of rainwater (Wong 2006; Philip 2011). The mentioned spatial definition for urban fabrics refers to the design of roadways (Ignatieva et al. 2008); public open spaces (Tardin 2013); blue and greenways (Xiu et al. 2020); building lots (Ramboll 2016); areas to be occupied by the buildings and conditions for their construction (Liao et al. 2016); lot occupation and its permeability (Watson and Adams 2011); among others;

ii. Functional principle - Weaving: refers to considering land-use (e.g., open spaces to be occupied or not, and their related uses/activities) to enable the whole functioning of water's connections (Liao 2012). It also contemplates promoting a functional articulation among urban fabric, water, and its banks, allowing a visual perception and local experience of exchange between people and nature (Lamond and Everett 2019) mediated by water in a longitudinal and transversal way (Beatley and Newman 2013; Tardin 2013).

This methodological approach has a qualitative focus. Its operationalisation includes: iconographic research, data collection, cartographic analysis, field observation, and recording information by photographs, sketches, and personal notes. Although this methodology framework is applied to a case study, it can be replicated to other realities.

\section{Case Study}

The city of Uberlândia has approximately 691,305 inhabitants (IBGE 2020) and is the second-largest municipality in Minas Gerais State, Brazil, considering its population. This city, located in the Triângulo Mineiro region (see Fig. 1), is a regional centrality for neighbouring towns. It is strategically situated concerning other important centralities in Brazil's Southeast and Midwest Regions.

From all municipality's territory $\left(4,115 \mathrm{Km}^{2}\right), 5.32 \%$ is classified as an urban area, while $94.68 \%$ is rural. On the other hand, the vast majority of its population (97.23\%) lives in the urban area, while only $2.77 \%$ of it remains in the countryside (IBGE 2020).

\subsection{Biophysical system}

\subsubsection{Hydrography}

The city of Uberlândia possesses a significant water system, part of two watersheds - Tijuco River and Araguari River - and comprises springs, streams, rivers, and flood plains. The Uberabinha River is the principal watercourse that crosses the urban area of Uberlândia (see Fig. 2). It is currently the primary water supply source and hydroelectric power generation source for this city. Inside the urban area, the vast majority of streams are Uberabinha River's tributary, and together they compose an extensive system of water capillarity covering the city's whole territory (see Fig. 3). Their characteristics are closely associated with factors as relief, vegetation, local climate, and soil.

\subsubsection{Topography and soil}

Uberlândia has a wavy relief with elevations from $800 \mathrm{~m}$ to $1,000 \mathrm{~m}$ and slight slopes around $30 \%$ (Baccaro et al. 2004). Wetlands, mainly characterised by hydromorphic soils, have an essential role in water and biological regulation in the watershed. This type of soil absorbs a large amount of rainwater during wet months, maintaining the hydrological balance all along the dry season. The presence of streams is remarkable in valley bottoms (see Fig. 4). During rainfall events, they are flooding points due to the water runoff that comes from impervious sidehills. These valley bottoms also have eroded stream banks and sedimented stream channels (Vital 2012). It shows the importance of considering topography and soil type for structuring urban development and preserving natural water drainage and the needed spaces for surface runoff and water accommodation.

\subsubsection{Vegetation}

The predominant biome in this region is Cerrado (savanna), besides the mesophilic forest present in the steepest hills (Baccaro et al. 2004). Currently, human impacts and fragmentation mark this biome, broadly replaced by cattle-raising areas and grain crops, such as 
soybeans and coffee (Minas Gerais 2015). However, the city still presents meaningful areas for preserving Cerrado's native vegetation (see Fig. 5), primarily associated with water bodies. Specifically, within the subwatershed of the Uberabinha River, it is possible to identify different vegetation forms such as grassland, palm swamp areas, savanna, forest-like savanna, riparian forests, and seasonal forests (Minas Gerais 2015). The veredas have an essential role in water and biological regulation for water bodies. These sites are generally associated with hydromorphic soils, covered by grassy vegetation and palms. All these biome's intrinsic characteristics must be observed for the systemic spatial planning strategy definitions.

\subsubsection{Climate}

The region's climate has a remarkable characteristic, a dry winter and a rainy summer. During rain scarcity, droughts cause water shortage concerns for urban consumption and fire events in shrubby areas, forests, and the countryside. Whereas, during rainy months, rainfall events cause serious flooding problems to built-up areas. It shows the urgency to consider water dynamics as a protagonist for the structuring of future urban development.

\subsection{Urban system}

The central region of Uberlândia is the city's first settlement area and presents a consolidated built-up site with varied land-uses. Here, it is possible to find a predominance of commerce, services, and the higher city's density rate. The average occupancy rate of lots in this central region is $60-70 \%$. The floor area ratio can reach 100\% when used for commerce or service (PMU 2011a). The urban fabric encompasses streams' and springs' massive channelling and grounding under roadways. Currently, these avenues play a structural role in the city's roadway system. At the same time, they are the main flood-prone areas during rainfall events.

The city's expansion process occurred radial and asymmetrical, within an extensive land occupation, compromising untouched woodlands and water bodies. This urban sprawl happened without any specific planning or regulatory legal guidelines for an extended period (Soares 1995). The subsequent urban development followed a logic of functional conformation, based on transport accessibility and the presence of urban infrastructure, where water dynamics were set aside regarding the design of buildings, lots, open spaces, and roadway infrastructure.

According to existing cartography and field observation, the most recent urban development shows monofunctional residential gated communities composed of houses or vertical buildings. These areas have few accesses and are linked to an extensive roadway system that connects to other parts of the city. From functional and spatial perspectives, they form introverted urban fabrics and functionally depend on other city centres. In many cases, streams and springs have some of their portions incorporated into these gated communities' interior, as they are not channelled and receive an aesthetic treatment. These cases are more frequent in the city's southeastern region. In this region, there are remaining adjacent farmland open spaces that can be occupied soon and represent the primary urban expansion vector. Water bodies are frequently considered "separating" elements in the urban fabric, representing, along with roadway infrastructure (such as avenues, highways, or railways), a physical and/or an administrative limit between neighbourhoods and different city regions.

\subsection{Planning rules}

Despite an unquestionable advance in Brazil regarding national environmental protection rules, a critical perspective on this theme is essential to protect water bodies and associated biophysical processes effectively. The legal protection of water bodies is essentially provided by the National Policy of Water Resources (Política Nacional de Recursos Hídricos) (Brasil 1997), and the Brazilian Forestry Code (Código Florestal Brasileiro) (Brasil 2012), and regulated by the Permanent Protection Areas (Áreas de Proteção Permanente APPs) and Conservation Units (Unidades de Conservação - UC) (Brasil 2000, 2012).

The UCs are large areas of integral protection or sustainable use areas to protect ecosystems and their full functioning. The APPs are protected spaces with or without native vegetation whose objective is to preserve biophysical dynamics (e.g., water resources, biodiversity, soil and geological stability, the flow of flora and fauna). This instrument establishes a minimum area around watercourses to protect the water bodies, banks, and associated vegetation (see Table 2). These rules are equally applied to rural or urban areas, and, as abstract measures, they do not always meet the spatial and functional needs of local hydrological dynamics. Such issue often generates an intense debate in this field (Metzger 2010; Gomes et al. 2012; Sepe et al. 2014).

Meanwhile, it is a municipal responsibility to adapt and broaden the APPs' protection rule to meet local specificities regarding the ecosystem's functions and ensure an effective continuity and satisfactory functioning of the biophysical processes they intend to 
protect. However, in practice, it is possible to observe the exact replication of a federal generalist rule at the municipal level (see Tables 1 and 2), as is the municipal Ordinary Law 10.700/2011 (PMU 2011c) in the city of Uberlândia.

It shows that the city's spatial planning does not contemplate the actual water dynamics' needs, whether functional or spatial. On the contrary, the plan extensively prioritises urbanisation demands, such as maximising land development and urban infrastructure (see Table 1).

Table 1

The legal framework of current urban rules related to water bodies' protection applied in Uberlândia.

Source: from Brasil (1979), PMU (2011a, 2011b and 2006)

\begin{tabular}{|c|c|c|c|}
\hline Subject & Law & Instance & Protection and regulatory measures \\
\hline $\begin{array}{l}\text { Urban land } \\
\text { subdivision }\end{array}$ & $\begin{array}{l}\text { Federal Law } \\
\text { no. } \\
6.766 / 1979\end{array}$ & Federal & $\begin{array}{l}\text { It defines a minimum wide of } 15 \mathrm{~m} \text { of a non-buildable strip along watercourses or } \\
\text { highways. Urban development is not allowed on areas with a slope greater than or } \\
\text { equal to } 30 \% \text {, inside ecological preservation areas, wetlands, and flooding-prone } \\
\text { locations. An urban drainage system is mandatory in every settlement. }\end{array}$ \\
\hline $\begin{array}{l}\text { Urban land } \\
\text { subdivision }\end{array}$ & $\begin{array}{l}\text { Supplementary } \\
\text { Law no. } \\
523 / 2011\end{array}$ & Municipal & $\begin{array}{l}\text { It sets the same restrictions as the Federal law above. Additions: in an urban } \\
\text { residential fabric, open public spaces must correspond to } 9 \% \text { of the total area - of } \\
\text { which } 35 \% \text { can be impervious ground. }\end{array}$ \\
\hline $\begin{array}{l}\text { Director } \\
\text { Plan for } \\
\text { Uberlândia }\end{array}$ & $\begin{array}{l}\text { Supplementary } \\
\text { Law no. } \\
432 / 2006\end{array}$ & Municipal & $\begin{array}{l}\text { It defines the Macrozone for the Water Sources Protection Area, which restricts the } \\
\text { urban sprawl in the southern region beyond the Uberabinha River's limits. In the } \\
\text { northwest region, it delimits the Macrozone of Tourism and Leisure, which } \\
\text { encompasses the final path of the Uberabinha River, where only the development of } \\
\text { activities that contributes to ecological protection is allowed. }\end{array}$ \\
\hline $\begin{array}{l}\text { Land-use } \\
\text { and } \\
\text { occupation } \\
\text { zoning } \\
\text { regulation }\end{array}$ & $\begin{array}{l}\text { Supplementary } \\
\text { Law no. } \\
525 / 2011\end{array}$ & Municipal & $\begin{array}{l}\text { It defines the Protection and Leisure Zone - valley bottoms and parks -, where it is } \\
\text { forbidden urban development. Briefly, it coincides with the area already delimited by } \\
\text { APPs, which borders rivers, streams, and springs inside the urban perimeter. }\end{array}$ \\
\hline
\end{tabular}

Table 2

Legal framework of current environmental rules related to water bodies' protection applied in Uberlândia.

Source: Brasil (2000 and 2012), PMU (2011c and 2006)

\begin{tabular}{|c|c|c|c|}
\hline Subject & Law & Instance & Protection and regulatory measures \\
\hline $\begin{array}{l}\text { National Policy of } \\
\text { Water Resources }\end{array}$ & $\begin{array}{l}\text { Federal Law } \\
\text { no. } \\
9.433 / 1997\end{array}$ & Federal & $\begin{array}{l}\text { It defines water as an asset of the public domain that must be preserved } \\
\text { sustainably. Water resources must count with decentralized management, } \\
\text { articulated between national and regional planning, and integrated into } \\
\text { environmental policies. }\end{array}$ \\
\hline $\begin{array}{l}\text { National System of } \\
\text { Nature } \\
\text { Conservation Units }\end{array}$ & $\begin{array}{l}\text { Federal Law } \\
\text { no. } \\
9.985 / 2000\end{array}$ & Federal & $\begin{array}{l}\text { According to the territory's biophysical characteristics, it defines } \\
\text { Conservation Units as large areas of integral protection or sustainable use. }\end{array}$ \\
\hline $\begin{array}{l}\text { Brazilian Forestry } \\
\text { Code }\end{array}$ & $\begin{array}{l}\text { Federal Law } \\
\text { no. } \\
12.651 / 2012\end{array}$ & Federal & $\begin{array}{l}\text { It defines APPs minimum protected spaces: a thirty-meter-wide strip along } \\
\text { watercourses (it varies according to the wide of a river/stream reach); a } \\
\text { radius of } 30 \mathrm{~m} \text { around urban lakes, lagoons, and wetlands; a radius of } 50 \mathrm{~m} \\
\text { around springs. }\end{array}$ \\
\hline $\begin{array}{l}\text { Environmental } \\
\text { protection, control, } \\
\text { and conservation } \\
\text { policy }\end{array}$ & $\begin{array}{l}\text { Ordinary Law } \\
\text { no. } \\
10.700 / 2011\end{array}$ & Municipal & $\begin{array}{l}\text { It defines APPs minimum protected spaces indicating the exact dimensions } \\
\text { proposed by the federal law above, without adapting to the local context. }\end{array}$ \\
\hline $\begin{array}{l}\text { Urban Plan for } \\
\text { Uberlândia }\end{array}$ & $\begin{array}{l}\text { Supplementary } \\
\text { Law no. } \\
432 / 2006\end{array}$ & Municipal & $\begin{array}{l}\text { It indicates the necessity of ecological recovery of valley bottoms, springs, } \\
\text { and streams as a municipal guideline to create an integrated urban system } \\
\text { of linear parks and municipal Conservation Units. }\end{array}$ \\
\hline
\end{tabular}

\section{Results And Discussion}

\subsection{Interface patterns between existing built-up areas and stream and springs}


The following interface patterns between built-up areas and streams and springs highlight related problems and potentialities concerning water dynamics full functioning within the whole municipality, to discuss further the potential of streams and springs to structure future urban development:

\subsubsection{Pattern 01: urban fabric with streams/springs channelised under the roadway infrastructure}

In this pattern, streams and springs are channelled under the roadway infrastructure (see Fig. 7), while urban dynamics condition their functional and spatial processes. There is a complete suppression of the riparian forest, an alteration of soil and topography, and, consequently, the compromise of the whole functioning of water dynamics.

There is no spatial or functional connection between the streams and urban fabrics (see Fig. 6) predominantly occupied by commerce or services. Due to the significantly ground imperviousness of this valley, the absence of water infiltration areas, and the rapid overflow of underground galleries, this pattern is characterised by frequent flooding during rainfall events.

This pattern occurs in the oldest region of the city - the central one - and precedes a local environmental policy to protect the ecosystem.

This pattern configures a model to be avoided in future urban developments due to the lack of integration between urban and biophysical dynamics (see Table 3). Suppressing the necessary spaces for the water cycle's proper functioning and the associated biophysical dynamics generates structural problems in the urban environment, such as flooding.

\subsubsection{Pattern 02: stream/spring + APP + back of the plot within the urban fabric}

In pattern 02, both the streams and springs are preserved inside the APP (see Fig. 8), having their biophysical dynamics protected only within those protection limits determined by the planning rules. Consequently, there is a rupture among the biophysical dynamics that occur outside and inside the APP, while the surrounding urban fabric outlines the insular protected space (see Fig. 8 and 9).

Land-use in these areas is predominantly residential or services - such as restaurants and rental leisure gardens -, and buildings occupy the centre of the lot. In this case, the protected space is adjacent to the back of lots or dead-end streets (see Fig. 8), with no social access to this area. The spatial separation between the urban fabric and the protected space occurs due to walls, gates, or fences, reflecting the absence of a functional interrelation amidst them (see Fig. 9).

The planning rules are respected, but locally it is observed the direct application of the minimum dimensions indicated for the APP, without considering the water dynamics' local needs. There are no legal guidelines for impact mitigation of urban fabrics on protected spaces, so the planning rules contribute to the segmentation between the urban fabrics and the water dynamics.

This pattern points to the need to create more spaces for water dynamics beyond the already legally protected areas and the necessity to provide greater visibility to the presence of streams and springs and their intrinsic processes (see Table 3 ).

\subsubsection{Pattern 03: stream/spring inside a large property within the urban fabric}

In pattern 03, springs and streams are found inside large properties - private or public - in built-up areas within the urban perimeter. The APP preserves these water bodies and maintains the native vegetation (see Fig. 10).

In general, land-use is residential - gated communities -, university campuses, industries, and clubs. In most cases, the soil has a high permeability rate, with large open spaces associated with the legally protected spaces, enabling the continuity of biophysical dynamics (see Fig. 10). In contrast, these large properties' immediate surroundings are usually dense, functionally, and spatially separated from the nearby water bodies (see Fig. 11).

Once more, planning rules are respected, and the minimum dimensions of protected spaces are expanded inside some properties. There are no legal instruments that encourage integrating urban fabrics and water dynamics. 
This pattern buffers impacts around the streams and springs and their APP through added open space. However, the existing land-use is not always appropriate and can negatively affect the water bodies' biophysical dynamics, e.g., waste disposal (see Table 3). A possible future interrelationship between urban fabrics and water bodies may be proposed by intertwining both realities.

\subsubsection{Pattern 04: stream/spring + APP + marginal street + urban fabric}

In pattern 04, streams and springs have their biophysical dynamics protected inside the APP. However, the surrounding urban fabric shapes this space, forming an insular area that enforces external urban pressure (see Fig. 12).

This pattern is the most common in the city. There is a marginal street separating the APP, limiting the riparian forest and serving the built-up area (see Fig. 13). This street's implementation aims to provide access to the stream, even though fences and no access indication often surround the APP area. Commonly, the urban fabric turns its back to this area without a spatial or functional relationship, setting the existing hydrologic dynamic aside.

Again, despite the vital role that the planning rules have for protecting water bodies and their dynamics, they favour a fragmented conception between the biophysical dynamics and the urban fabrics.

In this pattern, the urban fabric's detachment concerning the APP by a marginal street brings accessibility to this space. However, there is a lack of signs indicating a protected space associated with a watercourse. Simultaneously, a transition with an effective integration between the built-up space and the preserved environment is necessary, with spatial and functional interrelationships between these two instances (see Table 3).

\subsubsection{Pattern 05: stream/spring + APP + linear park + marginal street + urban fabric}

In pattern 05, streams and springs not only have their space and associated dynamics protected, but there is an expansion of this area by the presence of an adjacent linear park (see Fig. 14). The biophysical dynamics have a broader field, although they do not structure the urban occupation yet. They are limited within the area defined for the APP and the park.

Besides the existing larger open space, there is a significant artificialisation of the marginal space. Access to the protected space is allowed, but still practically does not exist a functional or spatial integration between the protected area and the urban fabric, reinforcing the separation between these two spaces (see Fig. 15).

The legal implementation of a linear park favours its use and perception by the population, generating an essential recognition of the water bodies and a sense of preservation of this collective asset. However, the legislation still understands the urban and biophysical instances as separate domains where the former exists in the latter's absence.

The potential to give more prominence to the water dynamics and environment, together with the possibility of urban recognition and social engagement, is a potential of this pattern that can be kept in future urban developments. On the other hand, planning improvement for effective integration between urban and biophysical instances may significantly advance their functional and spatial connections (see Table 3).

\subsubsection{Pattern 06: stream/spring inside a conservation unit}

In this case, springs and streams are protected within a Conservation Unit and identified as an urban park. Some of these parks are not open to public visitation, such as when the Conservation Unit has the unique function of protecting and maintaining the local ecosystem. There is an enlargement of the area reserved for the functioning of biophysical dynamics when compared to the minimum dimension of the APP, enabling an ecosystem richness. These biophysical dynamics structure land-use inside the park, but not outside (see Fig. 16).

This model allows social appropriation, public recognition of environmental values and may encourage a sense of preservation. These Conservation Units are spatially closed with gates and fences restricting social access through a specific entrance and limited periods.

In this case, the planning rules favour the protection of the stream and springs as they expand the minimum APP limits and its recognition and presence within the urban fabric. Nevertheless, they continue to provide a segmented relationship between urban fabrics and protected spaces. Here, built-up spaces and parks are developed tangentially and not interrelated (see Fig. 17). 
Although this pattern highlights water bodies and their biophysical processes, it is still necessary to strengthen functional and spatial interrelations between urban fabrics and water dynamics (see Table 3). 
Table 3

Problems and potentialities according to current pattern analysis and guidelines for structuring future urban fabric.

Source: Authors

\begin{tabular}{|c|c|c|c|c|c|c|c|}
\hline \multirow[t]{2}{*}{ Elements } & & \multicolumn{2}{|l|}{ Problems } & \multicolumn{2}{|l|}{ Potentialities } & \multicolumn{2}{|l|}{ Guidelines } \\
\hline & & $\begin{array}{l}\text { Spatial and } \\
\text { functional }\end{array}$ & Pattern & $\begin{array}{l}\text { Spatial and } \\
\text { functional }\end{array}$ & Pattern & Spatial & Functional \\
\hline \multirow[t]{14}{*}{$\begin{array}{l}\text { Biophysical } \\
\text { systems }\end{array}$} & \multirow[t]{6}{*}{ Water } & $\begin{array}{l}\text { - channelled water } \\
\text { body grounded } \\
\text { under roadway } \\
\text { infrastructure; }\end{array}$ & 01 & \multirow[t]{3}{*}{$\begin{array}{l}\text { - protected } \\
\text { spaces for the } \\
\text { overflow of the } \\
\text { watercourse; }\end{array}$} & \multirow[t]{3}{*}{$\begin{array}{l}02,03 \\
04,05 \\
06\end{array}$} & \multirow{6}{*}{$\begin{array}{l}\text { - protect water } \\
\text { spaces and } \\
\text { flow, without } \\
\text { interrupting, } \\
\text { strangling, or } \\
\text { channelling } \\
\text { them; } \\
\text { - ensure } \\
\text { physical } \\
\text { continuity } \\
\text { between stream, } \\
\text { flooding areas, } \\
\text { floodplains, and } \\
\text { springs; } \\
\text { - provide } \\
\text { visibility to the } \\
\text { water dynamics; }\end{array}$} & \multirow{6}{*}{$\begin{array}{l}\text { - identify } \\
\text { spaces outside } \\
\text { the APP where } \\
\text { critical } \\
\text { processes } \\
\text { occur for the } \\
\text { full functioning } \\
\text { of the water } \\
\text { cycle; } \\
\text { - favour the } \\
\text { ecosystem's } \\
\text { exchanges } \\
\text { between the } \\
\text { stream's } \\
\text { channel and } \\
\text { the entire } \\
\text { fluvial } \\
\text { structure: } \\
\text { riparian } \\
\text { vegetation, } \\
\text { soil, and } \\
\text { topography; } \\
\text { - ensure water } \\
\text { spaces as } \\
\text { structuring } \\
\text { asset for the } \\
\text { urban } \\
\text { occupation; }\end{array}$} \\
\hline & & $\begin{array}{l}\text { - APP with } \\
\text { minimum legal } \\
\text { dimensions; }\end{array}$ & $\begin{array}{l}02,03 \\
04,05\end{array}$ & & & & \\
\hline & & $\begin{array}{l}\text { - runoff rainwater } \\
\text { flows into streams } \\
\text { without any } \\
\text { filtering treatment; }\end{array}$ & $\begin{array}{l}02,04 \\
05\end{array}$ & & & & \\
\hline & & $\begin{array}{l}\text { - sedimentation of } \\
\text { the stream's } \\
\text { channel; }\end{array}$ & 02,04 & \multirow{3}{*}{$\begin{array}{l}\text { - the stream } \\
\text { maintains its } \\
\text { functional and } \\
\text { spatial } \\
\text { connection with } \\
\text { local } \\
\text { topography, } \\
\text { vegetation, and } \\
\text { soil; }\end{array}$} & \multirow[t]{3}{*}{$\begin{array}{l}02,03 \\
04,05 \\
06\end{array}$} & & \\
\hline & & $\begin{array}{l}\text { - clandestine } \\
\text { sewage } \\
\text { connections; }\end{array}$ & 02,04 & & & & \\
\hline & & $\begin{array}{l}\text { - interventions } \\
\text { within the stream's } \\
\text { channel to create } \\
\text { artificial tanks or } \\
\text { lakes; }\end{array}$ & 03 & & & & \\
\hline & \multirow[t]{3}{*}{ Topography } & $\begin{array}{l}\text { - natural } \\
\text { topography } \\
\text { completely } \\
\text { modified; }\end{array}$ & 01 & $\begin{array}{l}\text { - natural } \\
\text { topography } \\
\text { protected inside } \\
\text { the APP; }\end{array}$ & $\begin{array}{l}02,03 \\
04,05 \\
06\end{array}$ & \multirow{3}{*}{$\begin{array}{l}\text { - maintain } \\
\text { vegetated } \\
\text { slopes to } \\
\text { mitigate erosion } \\
\text { risk and } \\
\text { vigorous runoff } \\
\text { rainwater; } \\
\text { - recognize and } \\
\text { preserve } \\
\text { floodplains; }\end{array}$} & \multirow{3}{*}{$\begin{array}{l}\text { - take } \\
\text { advantage of } \\
\text { local } \\
\text { topography to } \\
\text { guide land use; } \\
\text { - favour natural } \\
\text { axes for water } \\
\text { flow; }\end{array}$} \\
\hline & & $\begin{array}{l}\text { - significant } \\
\text { interventions in } \\
\text { topography by the } \\
\text { urban } \\
\text { development; }\end{array}$ & $\begin{array}{l}02,03 \\
04,05 \\
06\end{array}$ & $\begin{array}{l}\text { - maintenance } \\
\text { of floodplains } \\
\text { outside the } \\
\text { APP; }\end{array}$ & $\begin{array}{l}03,05 \\
06\end{array}$ & & \\
\hline & & $\begin{array}{l}\text { - drained } \\
\text { floodplains in } \\
\text { urban fabric; }\end{array}$ & $\begin{array}{l}02,04 \\
05,06\end{array}$ & $\begin{array}{l}\text { - topography } \\
\text { guides land- } \\
\text { use; }\end{array}$ & 05,06 & & \\
\hline & \multirow[t]{4}{*}{ Vegetation } & $\begin{array}{l}\text { - riparian forest } \\
\text { suppression; }\end{array}$ & 01 & \multirow{2}{*}{$\begin{array}{l}\text { - native } \\
\text { vegetation } \\
\text { remains } \\
\text { protected within } \\
\text { the APP as a } \\
\text { shelter for local } \\
\text { fauna; }\end{array}$} & \multirow{2}{*}{$\begin{array}{l}02,03 \\
04,05 \\
06\end{array}$} & \multirow{4}{*}{$\begin{array}{l}\text { - promote } \\
\text { actions to } \\
\text { maintain native } \\
\text { vegetation } \\
\text { masses; } \\
\text { - control } \\
\text { deforestation on } \\
\text { new urban } \\
\text { fabric; }\end{array}$} & \multirow{4}{*}{$\begin{array}{l}\text { - identify } \\
\text { spaces outside } \\
\text { the minimum } \\
\text { APP width } \\
\text { where } \\
\text { significant } \\
\text { ecosystem } \\
\text { services take } \\
\text { place to guide } \\
\text { legal } \\
\text { regulations; }\end{array}$} \\
\hline & & $\begin{array}{l}\text { - irregular land-use } \\
\text { causing } \\
\text { deforestation spots } \\
\text { (for housing or } \\
\text { pasture); }\end{array}$ & 02,04 & & & & \\
\hline & & $\begin{array}{l}\text { - urban waste } \\
\text { disposal; }\end{array}$ & 02,04 & \multirow{2}{*}{$\begin{array}{l}\text { - expansion of } \\
\text { green open } \\
\text { spaces beyond } \\
\text { the APP; }\end{array}$} & \multirow[t]{2}{*}{$\begin{array}{l}03,05 \\
06\end{array}$} & & \\
\hline & & $\begin{array}{l}\text { - lack of open } \\
\text { space continuity } \\
\text { outside the APP; }\end{array}$ & 02,04 & & & & \\
\hline & Soil & - impervious soil; & 01 & $\begin{array}{l}\text { - preservation } \\
\text { of } \\
\text { hydromorphic }\end{array}$ & $\begin{array}{l}02,03 \\
04,05 \\
06\end{array}$ & $\begin{array}{l}\text { - maintain } \\
\text { spatial } \\
\text { continuity } \\
\text { connections }\end{array}$ & $\begin{array}{l}\text { - protect } \\
\text { significant } \\
\text { areas of water } \\
\text { infiltration, }\end{array}$ \\
\hline
\end{tabular}

Page $11 / 40$ 


\begin{tabular}{|c|c|c|c|c|c|c|c|}
\hline & & & & \multicolumn{2}{|l|}{$\begin{array}{l}\text { soils within the } \\
\text { APP; }\end{array}$} & \multirow{2}{*}{$\begin{array}{l}\text { between } \\
\text { hydromorphic } \\
\text { soils and the } \\
\text { stream/spring; }\end{array}$} & \multirow[t]{2}{*}{$\begin{array}{l}\text { even outside } \\
\text { the APP; }\end{array}$} \\
\hline & & $\begin{array}{l}\text { - erosion spots with } \\
\text { ravines or gullies; }\end{array}$ & $\begin{array}{l}02,03, \\
04\end{array}$ & $\begin{array}{l}\text { - expansion of } \\
\text { infiltration } \\
\text { areas; }\end{array}$ & $\begin{array}{l}03,05 \\
06\end{array}$ & & \\
\hline \multirow[t]{12}{*}{$\begin{array}{l}\text { Urban } \\
\text { systems }\end{array}$} & \multirow[t]{5}{*}{$\begin{array}{l}\text { Roadway } \\
\text { infrastructure }\end{array}$} & $\begin{array}{l}\text { - roadway } \\
\text { infrastructure over } \\
\text { a stream; }\end{array}$ & 01 & \multirow{2}{*}{$\begin{array}{l}\text { - soil } \\
\text { permeability } \\
\text { through the } \\
\text { vegetated } \\
\text { pedestrian } \\
\text { island; }\end{array}$} & \multirow[t]{2}{*}{$\begin{array}{l}01,02 \\
04,05\end{array}$} & \multirow{5}{*}{$\begin{array}{l}\text { - design water } \\
\text { accommodation } \\
\text { spaces within } \\
\text { the roadway } \\
\text { infrastructure; } \\
\text { - associate } \\
\text { roadway system } \\
\text { layout with the } \\
\text { natural axes of } \\
\text { rainwater } \\
\text { drainage; }\end{array}$} & \multirow{5}{*}{$\begin{array}{l}\text { - provide a } \\
\text { multifunctional } \\
\text { character to } \\
\text { the roadway } \\
\text { infrastructure } \\
\text { in integration } \\
\text { with the } \\
\text { ecosystem } \\
\text { services; }\end{array}$} \\
\hline & & $\begin{array}{l}\text { - high } \\
\text { imperviousness } \\
\text { rate; }\end{array}$ & $\begin{array}{l}02,04 \\
05,06\end{array}$ & & & & \\
\hline & & $\begin{array}{l}\text { - implementation of } \\
\text { roadway layout } \\
\text { transversally to the } \\
\text { natural drainage } \\
\text { system, favouring } \\
\text { water bodies' } \\
\text { sedimentation } \\
\text { from runoff } \\
\text { rainwater; }\end{array}$ & 02,04 & $\begin{array}{l}\text { - the marginal } \\
\text { street provides } \\
\text { physical and } \\
\text { visual } \\
\text { accessibility to } \\
\text { the stream's } \\
\text { area; }\end{array}$ & $\begin{array}{l}04,05 \\
06\end{array}$ & & \\
\hline & & $\begin{array}{l}\text { - streets without } \\
\text { spatial and } \\
\text { functional } \\
\text { integration with the } \\
\text { biophysical } \\
\text { dynamics; }\end{array}$ & $\begin{array}{l}01,02 \\
03,04 \\
05,06\end{array}$ & \multirow{2}{*}{$\begin{array}{l}\text { - } \\
\text { of bicycle } \\
\text { paths, } \\
\text { attracting } \\
\text { social } \\
\text { participation to } \\
\text { the space; }\end{array}$} & \multirow[t]{2}{*}{05,06} & & \\
\hline & & $\begin{array}{l}\text { - unpaved marginal } \\
\text { street beside APP; }\end{array}$ & 04 & & & & \\
\hline & \multirow[t]{4}{*}{ Lots } & $\begin{array}{l}\text { - high soil } \\
\text { imperviousness } \\
\text { rate; }\end{array}$ & $\begin{array}{l}01,02 \\
04,05 \\
06\end{array}$ & \multirow{2}{*}{$\begin{array}{l}\text { - physical } \\
\text { barrier to } \\
\text { control social } \\
\text { access to the } \\
\text { APP in cases of } \\
\text { environmentally } \\
\text { vulnerable } \\
\text { areas; }\end{array}$} & \multirow[t]{2}{*}{02,03} & \multirow{4}{*}{$\begin{array}{l}\text { - create spots of } \\
\text { native } \\
\text { vegetation } \\
\text { inside the lots to } \\
\text { promote } \\
\text { biophysical } \\
\text { continuity; }\end{array}$} & \multirow{4}{*}{$\begin{array}{l}\text { - increase } \\
\text { rainwater } \\
\text { absorption } \\
\text { within the lots, } \\
\text { avoiding } \\
\text { additional } \\
\text { runoff to the } \\
\text { roadway } \\
\text { infrastructure; }\end{array}$} \\
\hline & & $\begin{array}{l}\text { - no spatial or } \\
\text { functional } \\
\text { connection with the } \\
\text { APP; }\end{array}$ & $\begin{array}{l}02,04 \\
05,06\end{array}$ & & & & \\
\hline & & $\begin{array}{l}\text { - the lot hides } \\
\text { stream and spring; }\end{array}$ & 02,03 & \multirow{2}{*}{$\begin{array}{l}\text { - lower density } \\
\text { and higher soil } \\
\text { permeability } \\
\text { rate; }\end{array}$} & \multirow[t]{2}{*}{03} & & \\
\hline & & $\begin{array}{l}\text { - no treatment for } \\
\text { runoff rainwater; }\end{array}$ & $\begin{array}{l}01,02 \\
03,04 \\
05,06\end{array}$ & & & & \\
\hline & Buildings & $\begin{array}{l}\text { - lack of strategies } \\
\text { for rainwater } \\
\text { interception and } \\
\text { absorbency; }\end{array}$ & $\begin{array}{l}01,02 \\
03,04 \\
05,06\end{array}$ & none & - & $\begin{array}{l}\text { - use built } \\
\text { instruments to } \\
\text { intercept, } \\
\text { harvest, and } \\
\text { reuse rainwater; }\end{array}$ & $\begin{array}{l}\text { - promote } \\
\text { actions to } \\
\text { increase } \\
\text { permeability } \\
\text { and rainwater } \\
\text { infiltration } \\
\text { within the lot; }\end{array}$ \\
\hline & \multirow[t]{2}{*}{ Open spaces } & $\begin{array}{l}\text { - no spatial or } \\
\text { functional } \\
\text { interrelation } \\
\text { between APP and } \\
\text { open spaces that } \\
\text { are inside urban } \\
\text { fabric; }\end{array}$ & $\begin{array}{l}02,04 \\
05,06\end{array}$ & $\begin{array}{l}\text { - open spaces } \\
\text { associated with } \\
\text { the APP; }\end{array}$ & $\begin{array}{l}03,05 \\
06\end{array}$ & \multirow[t]{2}{*}{$\begin{array}{l}\text { - generate } \\
\text { spatial } \\
\text { connections } \\
\text { between open } \\
\text { spaces within } \\
\text { the urban fabric } \\
\text { and protected } \\
\text { spaces; }\end{array}$} & \multirow[t]{2}{*}{$\begin{array}{l}\text { - generate } \\
\text { functional } \\
\text { continuity } \\
\text { between } \\
\text { ecosystem } \\
\text { services and } \\
\text { urban open } \\
\text { spaces; }\end{array}$} \\
\hline & & $\begin{array}{l}\text { - lack of spatial or } \\
\text { functional } \\
\text { interrelationship } \\
\text { between APP and } \\
\text { contiguous open } \\
\text { spaces; }\end{array}$ & $\begin{array}{l}03,05 \\
06\end{array}$ & $\begin{array}{l}\text { - leisure urban } \\
\text { equipment } \\
\text { (bicycle path, } \\
\text { benches, } \\
\text { walking tracks, } \\
\text { playgrounds, } \\
\text { and outdoor } \\
\text { gyms); }\end{array}$ & 05,06 & & \\
\hline
\end{tabular}




\subsection{Systemic spatial planning strategies and alternative urban-eco system patterns}

The systemic spatial planning strategies are actions proposed according to the previous case study analysis, seeking hydrologic functioning and the future urban development structuring intertwined with water dynamics by presenting new urban-eco system patterns. The following systemic spatial planning strategies are proposed (see Table 4):

\subsubsection{Demarcating}

Demarcating denotes the need to recognise spaces by emphasising the areas already protected and delimiting those not yet protected as a critical path for the whole water dynamics' functioning (Tardin 2013). The demarcation for these functions' continuity must occur since the beginning of a new urban developing planning (Woods-Ballard et al. 2015).

Concerning planning policies and legislation, demarcating emphasises the urgency to elaborate a local drainage plan that contemplates: flooding areas, drainage axes, open space system, connections with the topography, and, lastly, a proposal for the management of the urban waters in a more sustainable and resilient way (Miguez et al. 2019).

It would also be essential to develop an environmental plan that integrates landscape mosaics, water bodies, and conservation units into a single document, discouraging fragmentation and providing an articulation among protected spaces (Xiu et al. 2020). It is highly recommended to think about both plans in an inter-relational and multidisciplinary way so that together they can structure the policy for urban land-use. Both plans should be combined with the proposition of a new urban-eco system pattern for areas to be demarcated.

In future urban development, demarcating would influence buildings, lots, roadways, and open spaces conception (see Fig. 18), and remark green spaces as a system for water accommodation (Liao et al. 2016), floodways, and ecological connections (Watson and Adams 2011). Demarcating must facilitate and communicate environmental values (Hough 1995) (see Table 4).

In the case study, demarcating concerns the local understanding of these processes and dynamics to adapt the minimum dimensions of the legal protection areas federally defined (Gomes et al. 2012), expanding them when necessary to provide adequate protection of the ecosystemic functions' continuity in its biome.

\subsubsection{Buffering}

Buffering refers to reducing urban impacts over streams and springs and their protected spaces, providing a generous space for the biophysical processes, and creating buffering zones that represent a shared area between urban fabrics and water dynamics (Watson and Adams 2011).

Concerning planning policies, the buffering action indicates adding qualitative parameters to the existing permeability and occupancy rate regulatory measures, such as the connection among permeable areas and the incentive to use and maintain the native vegetation (Watson and Adams 2011). Also, buffering may foment decentralised urban rainwater management through legal instruments, transferring to new built-up areas the responsibility to adopt compensatory impact measures (Philip 2011; Barbarossa et al. 2018).

In future urban development, new urban-eco system patterns must consider the land-use definition and urban elements to mitigate impacts over the existing biophysical elements and processes (see Table 4). These impacts could be managed in different scales as strategies to locate lots/buildings, roadway infrastructure, and open spaces (Wong 2006; Philip 2011; Watson and Adams 2011) (see Fig. 19). It is essential to consider synergic effects between urban and environmental spheres as part of a single landscape system (Tardin 2013).

\subsubsection{Concentrating}

Concentrating represents opposition regarding currently fragmented landscapes with extensive urban occupation by restricting the area available for built-up spaces. It is necessary to determine and concentrate growth vectors over specific areas suitable for urban expansion based on structuring biophysical assets (Barbedo et al. 2014). It allows for urban occupation in areas that will cause less impact on the ecosystem. Simultaneously, the action of concentrating implies in the fundamental analysis of the actual land demand for urban sprawl, being able, when possible, to increase density rates in some areas disfavouring the extensive land consumption. 
Thus, in spatial planning and regulatory guidelines, concentrating action implies defining priority axes for urban expansion, guided by identifying meaningful ecosystemic valuable areas and the environment's capacities (Miguez et al. 2019). At the same time, it proposes to control the density, occupancy, and permeability rates considering the location of water bodies and areas of significant groundwater recharge, to promote more compact regions when distant to these areas, minimising the impacts of urbanisation on water dynamics (Barbedo et al. 2014).

Regarding future urban-eco systems patterns, concentrating influences urban design in different scales, maintaining an integrated and unique system with surrounding open spaces (see Table 4). Buildings, lots, and roadway design would reflect occupancy's intention to concentrate and avoid extensive land consumption or even reserve built-up multifunctional areas reserved for the ecosystem's accommodation (Philip 2011; Ramboll 2016). Also, the lot's dimension and its occupancy rate would be guided by biophysical processes that already happen in that landscape, intending to favour it (Watson and Adams 2011) (see Fig. 20).

\subsubsection{Assimilating}

Assimilating refers to highlighting the water system in the urban landscape, allowing the assimilation of its presence. It is a strategy to provide visibility for the processes that support the water cycle, creating a collective awareness of its functioning and inciting a sense of environmental responsibility (Hough 1995; Beatley and Newman 2013). At the same time, it highlights the need to incorporate ecological processes in the urbanised landscape, accommodating water spaces inside urban fabrics and revealing to people their inherent dynamics as a design principle (Woods-Ballard et al. 2015; Liao et al. 2016).

From the perspective of new urban-eco system patterns, assimilating emphasises maintaining water's spaces inside protected areas and incorporating its needs and dynamics within urban design and built-up elements (Liao et al. 2016; Miguez et al. 2019). The intention is to create urban-eco systems that simulate the previously existing biophysical processes in the landscape while mitigating urbanisation impacts (see Fig. 21). This assimilation is feasible in many scales, such as: in buildings, by vegetated roofs and green facades (Ramboll 2016); in lots, by the presence of water regulation zones (Wong 2006); in roadways, by a layout with side rain gardens and street's paving (Ignatieva et al. 2008); and in open spaces, by constructed wetlands (Beatley and Newman 2013) (see Table 4).

Concerning planning policies, the assimilating action enables legal incentives to a more sensitive approach from urbanisation to the water cycle and its processes by favouring and allowing them to emerge in urban fabrics as mentioned above, accommodating water retention spaces, overflow, and movement. Besides, assimilating suggests the development of municipal technical manuals serving as a guide to urban design and infrastructures, adapting generic solutions to the local reality, and being inspired by water-centred initiatives such as blue-green infrastructure (Benedict and McMahon 2006; Ramboll 2016; Drosou et al. 2019) and Water Sensitive Urban Design (Wong 2006; Langenbach et al. 2008; Philip 2011). 
Table 4

Proposals for integrated spatial planning strategies encompassing functional and spatial perspectives to guide a structuring process of future urban fabrics

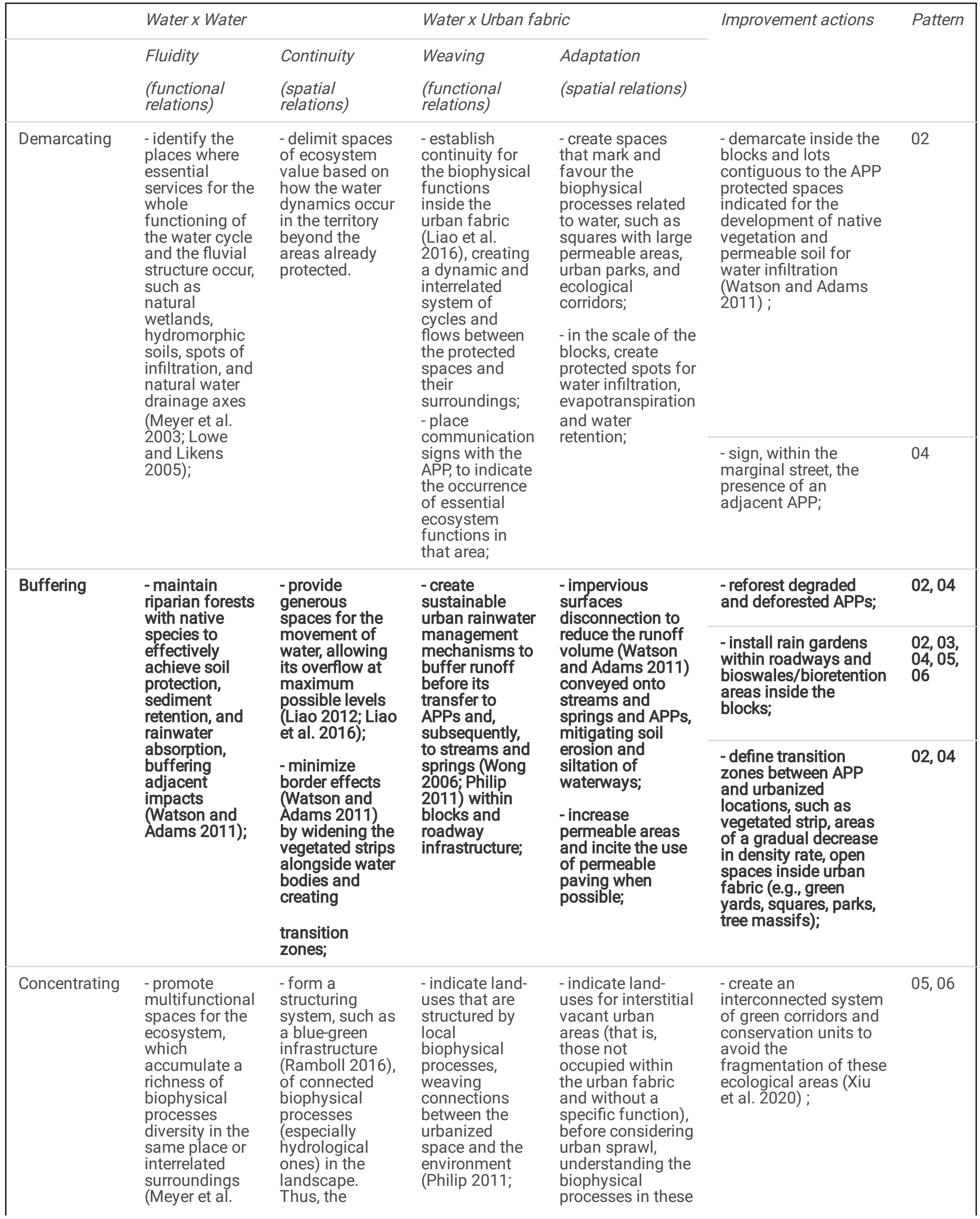




\begin{tabular}{|c|c|c|c|c|c|c|}
\hline & $\begin{array}{l}\text { 2003; Lowe } \\
\text { and Likens } \\
\text { 2005); }\end{array}$ & $\begin{array}{l}\text { already existing } \\
\text { system of } \\
\text { streams and } \\
\text { springs may } \\
\text { interconnect } \\
\text { forests and } \\
\text { natural } \\
\text { wetlands, } \\
\text { avoiding the } \\
\text { fragmentation } \\
\text { of the } \\
\text { ecosystem } \\
\text { services (Xiu et } \\
\text { al. 2020); }\end{array}$ & $\begin{array}{l}\text { Tardin } 2013 \\
\text { and 2017); }\end{array}$ & $\begin{array}{l}\text { locations and their } \\
\text { potentialities, such } \\
\text { as the definition of } \\
\text { a new protected } \\
\text { space, a green } \\
\text { corridor, or a place } \\
\text { for urban } \\
\text { development; }\end{array}$ & & \\
\hline \multirow[t]{2}{*}{ Assimilating } & \multirow[t]{2}{*}{$\begin{array}{l}\text { - enable all the } \\
\text { processes that } \\
\text { constitute the } \\
\text { hydrological } \\
\text { cycle: } \\
\text { evaporation, } \\
\text { precipitation, } \\
\text { percolation, } \\
\text { soil infiltration, } \\
\text { and } \\
\text { groundwater } \\
\text { recharge, } \\
\text { which, } \\
\text { subsequently, } \\
\text { will outflow } \\
\text { from the } \\
\text { ground as a } \\
\text { spring (Meyer } \\
\text { et al. 2003; } \\
\text { Lowe and } \\
\text { Likens 2005); }\end{array}$} & \multirow{2}{*}{$\begin{array}{l}\text { - provide } \\
\text { visibility to the } \\
\text { spaces where } \\
\text { essential } \\
\text { ecosystem } \\
\text { services occur, } \\
\text { not only } \\
\text { protecting them } \\
\text { by legal } \\
\text { measures but } \\
\text { also giving } \\
\text { legibility to } \\
\text { these areas } \\
\text { through } \\
\text { informative } \\
\text { communication, } \\
\text { visually } \\
\text { signalling } \\
\text { processes, open } \\
\text { access maps, } \\
\text { among others } \\
\text { (Riley 1998); }\end{array}$} & \multirow{2}{*}{$\begin{array}{l}\text { - define land- } \\
\text { use in a } \\
\text { compatible } \\
\text { way with the } \\
\text { existing } \\
\text { biophysical } \\
\text { environment, } \\
\text { identify local } \\
\text { opportunities } \\
\text { and } \\
\text { potentialities, } \\
\text { and engage } \\
\text { inhabitants } \\
\text { with the } \\
\text { landscape } \\
\text { processes } \\
\text { (Beatley and } \\
\text { Newman 2013; } \\
\text { Lamond and } \\
\text { Everett 2019). } \\
\text { Examples: } \\
\text { where } \\
\text { urbanization is } \\
\text { discouraged, } \\
\text { and the scenic } \\
\text { attributes are } \\
\text { significant, } \\
\text { such as } \\
\text { viewpoints, } \\
\text { walking tracks, } \\
\text { an open } \\
\text { museum; in } \\
\text { flooding-prone } \\
\text { areas: squares } \\
\text { and sports } \\
\text { fields with } \\
\text { hybrid } \\
\text { functionalities. }\end{array}$} & \multirow{2}{*}{$\begin{array}{l}\text { - create built-up } \\
\text { spaces that seek } \\
\text { to mimic the } \\
\text { biophysical } \\
\text { processes } \\
\text { previously existing } \\
\text { in the landscape, } \\
\text { mitigating the } \\
\text { impacts generated } \\
\text { by urbanization, } \\
\text { while inserting the } \\
\text { city within the } \\
\text { environmental } \\
\text { cycle (Beatley and } \\
\text { Newman 2013); } \\
\text { - build within the } \\
\text { city interconnected } \\
\text { green corridors, } \\
\text { bio-retention } \\
\text { basins, } \\
\text { constructed } \\
\text { wetlands, urban } \\
\text { parks (Beatley and } \\
\text { Newman 2013; } \\
\text { Benedict and } \\
\text { McMahon 2006; } \\
\text { Wong, 2006; } \\
\text { Barbedo et al. } \\
2014 ; \text { Woods- } \\
\text { Ballard et al. } \\
\text { 2015) }\end{array}$} & $\begin{array}{l}\text { - On a block scale: } \\
\text { create vegetated roofs, } \\
\text { green facades, } \\
\text { rainwater tanks, } \\
\text { permeable areas with } \\
\text { native vegetation, } \\
\text { porous pavement } \\
\text { (Wong 2006; Philip } \\
\text { 2011; Ramboll 2016). }\end{array}$ & $\begin{array}{l}02,03 \\
04,05 \\
06\end{array}$ \\
\hline & & & & & $\begin{array}{l}\text { - At a neighbourhood } \\
\text { scale: create rain } \\
\text { gardens, bioswales } \\
\text { and on-site rainwater } \\
\text { retention, street layout } \\
\text { sensitive to water flow, } \\
\text { urban vegetation } \\
\text { (Wong 2006; LUC } \\
\text { 2009; Woods-Ballard } \\
\text { et al. 2015; Ramboll } \\
\text { 2016). }\end{array}$ & $\begin{array}{l}02,03, \\
04,05, \\
06\end{array}$ \\
\hline
\end{tabular}

\section{Conclusion}

This paper proposed a methodological framework for systemic strategies for spatial planning (land-use and urban design guidelines) based on streams and springs as structuring elements of future urban development. Even protected by planning rules, water dynamics and associated biophysical processes remain fragmented and conditioned by urbanisation in most cities worldwide. In this context, this study put streams and springs, which are less contemplated in the current literature related to water bodies, as the vertebrate key elements for structuring future urban development, due to their significant potential to environmentally guide sensitive urban-eco systems patterns.

The analysis of existing built-up areas and their interface with streams and springs associated with the local planning regulations in the city of Uberlândia/Brazil showed patterns confirming that biophysical and urban processes, whether physically-spatially or through their rules, currently remain as instances that do not work as a system. The latter constantly conditions the former. This inter-related analysis allowed for identifying existing problems that prevent the water dynamics from structuring the urban fabrics and fully performing their functions simultaneously, and opportunities that show ways forward to achieving this goal. 
The systemic spatial planning strategies consist of actions - demarcating, buffering, concentrating, and assimilating - and correspond to local strategies that spatially and functionally consider the necessary spaces for the full functioning of water dynamics intertwined with land-use and urban design guidelines. The strategies may guide planning rules towards an environmental and urban integrated approach as a pathway to sustainable and resilient urban environments, attenuating the stream syndrome.

The proposed methodological framework has a substantial site knowledge component. It can be applied to different urban contexts, besides being a potent tool for the sustainable urban development of developing country cities.

Further research may include social participation and emphasise people's relationships with streams and springs in the urban environment, adding sociocultural attributes to the current methodological framework. On the other hand, project-based proposals applying the strategies may be formulated, pointing out possible future urban scenarios that could be mathematically modelled to evaluate the proposed planning strategies' efficacy quantitatively.

\section{Declarations}

\section{Acknowledgements}

The authors gratefully acknowledge the Professional Master in Landscape Architecture of Graduate Programme in Urban Planning from Federal University of Rio de Janeiro (PROURB/UFRJ); the Government of Brazil, Ministry of Education (Coordenação de Aperfeiçoamento de Pessoal de Nível Superior - Capes), for the academic support; and the Municipality of Uberlândia for the technical and documental support during the development of this research.

\section{Statements and Declarations}

The authors declare that no funds, grants, or other support were received during the preparation of this manuscript.

The authors have no relevant financial or non-financial interests to disclose

All authors contributed to the study conception and design. Material preparation, data collection and analysis were performed by Julia Figueiredo-Cunha and Raquel Tardin-Coelho. Both authors wrote, read and approved the final manuscript.

\section{References}

Arthington AH, Naiman RJ, McClain ME, Nilsson C (2010) Preserving the biodiversity and ecological services of rivers: new challenges and research opportunities. Freshw Biol. https://doi.org/10.1111/j.1365-2427.2009.02340.x

Baccaro C (2004) Mapeamento geomorfológico da bacia do Rio Araguari (MG).. In: In: Lima SC, Santos RJ (eds) Gestão ambiental da bacia do Rio Araguari - rumo ao desenvolvimento sustentável. Universidade Federal de Uberlândia / Instituto de Geografia, CNPq, Brasília, pp 1-19

Barbarossa L, Pappalardo V, Martinico F (2018) Building the resilient city - Strategies and tools for the city masterplan. UPLanD Journal of Urban Planning, Landscape \& Environmental Design 3(2):15-24

Barbedo J, Miguez M, Van Der Horst D, Marins M (2014) Enhancing ecosystem services for flood mitigation: a conservation strategy for peri-urban landscapes? Ecol Soc 19(2):54

Beatley T, Newman P (2013) Biophilic Cities Are Sustainable, Resilient Cities. Sustainability 5(3):3328-3345

Benedict MA, Mcmahon ET (2006) Green infrastructure: linking landscapes and communities. Island Press, Washington (DC)

BRASIL (1979) Lei Federal 6.766, de 19 de dezembro de 1979. Presidência da República, Brasília, Brazil. [online] URL:

http://www.planalto.gov.br/ccivil_03/LEIS/L6766.htm

(1997) Lei Federal 9.433, de 8 de janeiro de 1997. Presidência da República, Brasília, Brazil. [online] URL:

http://www.planalto.gov.br/ccivil_03/leis/l9433.htm

Page $17 / 40$ 
(2000) Lei Federal 9.985, de 18 de julho de 2000. Presidência da República, Brasília, Brazil. [online] URL:

http://www.planalto.gov.br/ccivil_03/leis//9985.htm

(2012) Lei Federal 12.651, de 25 de maio de 2012. Presidência da República, Brasília, Brazil. [online] URL:

http://www.planalto.gov.br/ccivil_03/_ato2011-2014/2012/lei/l12651.htm

Carmon N, Shamir U (2010) Water-sensitive planning: integrating water considerations into urban and regional planning. Water and Environment Journal. https://doi.org/10.1111/j.1747-6593.2009.00172.x

Childers DL, Cadenasso ML, Grove JM, Marshall V, Mcgrath B, Pickett STA (2015) An Ecology for Cities: A Transformational Nexus of Design and Ecology to Advance Climate Change Resilience and Urban Sustainability. Sustainability 7(4):3774-3791

Drosou N, Soetanto R, Hermawan F, Chmutina K, Bosher L, Hatmoko JUD (2019) Key Factors Influencing Wider Adoption of BlueGreen Infrastructure in Developing Cities. Water. https://doi.org/10.3390/w11061234

Fletcher TD, Shuster W, Hunt WF et al (2015) SUDS, LID, BMPs, WSUD and more - The evolution and application of terminology surrounding urban drainage. Urban Water Journal. https://doi.org/10.1080/1573062X.2014.916314

Gomes E, Name LE, Montezuma RCM (2012) Complexidade e Conflitos: APP, espaço geográfico e espaço normativo. In: Proceeding of the 2nd Seminário Nacional sobre Áreas de Preservação Permanente em Meio Urbano; May 9-11; Natal

Hough M (1995) Cities and natural process. Routledge, New York

[IBGE] IBGE, Cidades (2020) Brasilia, Brazil: Instituto Brasileiro de Geografia e Estatística; [accessed 2020 Nov 10].

https://cidades.ibge.gov.br/brasil/mg/uberlandia/panorama

Ignatieva M, Stewart G, Meurk C (2008) Low Impact Urban Design and Development (LIUDD): matching urban design and urban ecology. Landscape Review 12(2):61-73

Kloss C, Calarusse C (2006) Rooftops to rivers: Green strategies for controlling stormwater and combined sewer overflows. Natural Resources Defense Council, Low Impact Development Center, and University of Maryland School of Public Policy, Washington (DC)

Lamond J, Everett G (2019) Sustainable Blue-Green Infrastructure: A social practice approach to understanding community preferences and stewardship. Landscape and Urban Planning 191:103639

Langenbach H, Eckart J, Schröder G (2008) Water Sensitive Urban Design - results and principles. In: Proceedings of the 3rd SWITCH Scientific Meeting; Nov 30 - Dec 4; Belo Horizonte, Brazil

Liao K-H (2012) A theory on urban resilience to floods-a basis for alternative planning practices. Ecol Soc 17(4):48

Liao K-H (2014) From flood control to flood adaptation: a case study on the Lower Green River Valley and the City of Kent in King County, Washington. https://doi.org/10.1007/s11069-013-0923-4. Nat Hazards

Liao K-H, Anh Le T, Nguyen KV (2016) Urban design principles for flood resilience: Learning from the ecological wisdom of living with floods in the Vietnamese Mekong Delta. Landscape and Urban Planning 155:69-78

Lowe WH, Likens GE (2005) Moving headwater streams to the head of the class. Bioscience 55(3):196-197

[LUC] Land Use Consultants (2009) Natural England’s Green Infrastructure Guidance. Natural England. [place unknown]

Martin-Mikle CJ, De Beurs KM, Julian JP, Mayer PM (2015) Identifying priority sites for low impact development (LID) in a mixed-use watershed. Landscape and Urban Planning 140:29-41

Meyer JL, Kaplan LA, Newbold D et al (2003) Where rivers are born: The scientific imperative for defending small streams and wetlands. American Rivers, Sierra Club, Washington (DC)

Metzger JP (2010) O Código Florestal tem Base Científica? Natureza \& Conservação 8:92-99

Page $18 / 40$ 
Miguez MG, Veról AP, Battemarco BP et al (2019) A framework to support the surbanisation process on lowland coastal areas: Exploring the case of Vargem Grande - Rio de Janeiro, Brazil. J Clean Prod 231(10):1281-1293

Minas G (2015) Secretaria de Desenvolvimento Social - SEDESE. Conselho de Direitos Difusos do Estado de Minas Gerais; Associação para a Gestão Socioambiental do Triângulo Mineiro - ANGÁ. Diagnóstico Ambiental da Bacia Hidrográfica do Rio Uberabinha. Uberlândia, Brazil

Palazzo E (2019) From water sensitive to floodable: defining adaptive urban design for water resilient cities. Journal of Urban Design. https://doi.org/10.1080/13574809.2018.1511972

Philip R (2011) SWITCH Training Kit - Integrated urban water management in the city of the future. Module 4: Stormwater - Exploring the options. ICLEl European Secretariat, Freiburg. [accessed 2020 Nov 15] https://switchtraining.eu

Ramboll (2016) Making cities liveable: blue-green infrastructure and its impact on society. [place unknown]: Ramboll; [accessed 2020 Jul 1] https://ramboll.com/services-and-sectors/planning-and-urban-design/blue-green-infrastructure-design

Riley AL (1998) Restoring streams in cities: a guide for planners, policymarkers, and citizens. Island Press, Washington (DC)

Sepe PM, Pereira HMSB, Bellenzani ML (2014) O novo Código Florestal e sua aplicação em áreas urbanas: uma tentativa de superação ou de conflitos? In: Proceeding of the 3rd Seminário Nacional sobre o Tratamento de Áreas de Preservação Permanente em Meio Urbano e Restrições Ambientais ao Parcelamento do Solo; Sep 11-13; Belém, Brazil

Soares BR (1995) Uberlândia: da Cidade Jardim ao Portal do Cerrado - Imagens e representações no Triangulo Mineiro Dissertation, University of São Paulo

Spirn AW (1984) The granite Garden: urban nature and human design. Basic Books, New York

Tardin R (2013) System of Open Spaces: Concrete Project Strategies for Urban Territories. Springer, New York

Tardin R (2014) Landscape and urban planning: a systemic approach.. In: In: Amado MP (ed) Urban planning: practices, challenges and benefits. Nova Science Publishers, New York, pp 33-48

Tardin R (2017) Collective systemic landscape planning strategies: experience in Paraty, Rio de Janeiro, Brazil.. In: In: Daniels JA (ed) Advances in Environmental Research. Nova Science Publishers, New York

[PMU] Prefeitura Municipal de Uberlândia (2006) Lei complementar nº 432, de 19 de outubro de 2006. Uberlândia, Brazil (2011a) Lei complementar n 523, de 7 de abril de 2011. Uberlândia, Brazil (2011b) Lei complementar nº 525, de 14 de abril de 2011. Uberlândia, Brazil (2011c) Lei ordinária nº 10.700, de 9 de março de 2011. Uberlândia, Brazil (2017) Secretaria Municipal de Planejamento Urbano. Banco de Dados Integrados, vol 1. Uberlândia, Brazil Vital GTD (2012) Projeto sustentável para a cidade: o caso de Uberlândia. Dissertation, University of São Paulo Walsh CJ, Roy AH, Feminella JW et al (2005) The urban stream syndrome: current knowledge and the search for a cure. Journal of the North American Benthological Society. https://doi.org/10.1899/04-028.1

Wantzen KM, Alves CBM, Badiane SD et al (2019) Urban Stream and Wetland Restoration in the Global South-A DPSIR Analysis. Sustainability. https://doi.org/10.3390/su11184975

Watson D, Adams M (2011) Design for flooding: architecture, landscape and urban design for resilience to climate change. John Wiley \& Sons, Inc., Hoboken

Wenger SJ, Roy AH, Jackson CR et al (2009) Twenty-six key research questions in urban stream ecology: an assessment of the state of the science. Journal of the North American Benthological Society. https://doi.org/10.1899/08-186.1 
Wipfli MS, Richardson JS, Naiman RJ (2007) Ecological linkages between headwaters and downstream ecosystems: transport of organic matter, invertebrates, and wood down headwater channels. J Am Water Resour Assoc 43(1):72-85

Wong THF (2006) Water Sensitive Urban Design - The Journey Thus Far. Aust J Water Resour 10:213-222

Woods-Ballard B, Wilson S, Udale-Clarke H et al (2015) The SUDS Manual. CIRIA C753, London

Yaacovi Y, Gasith A, Becker N (2021) How much is an urban stream worth? Using land senses and economic assessment of an urban stream restoration. International Journal of Sustainable Development \& World Ecology.

https://doi.org/10.1080/13504509.2021.1929546

Xiu N, Ignatieva M, Van Den Bosch CK, Zhang S (2020) Applying a socio-ecological green network framework to Xi'an City, China. Landscape Ecol Eng 16:135-150

\section{Figures}

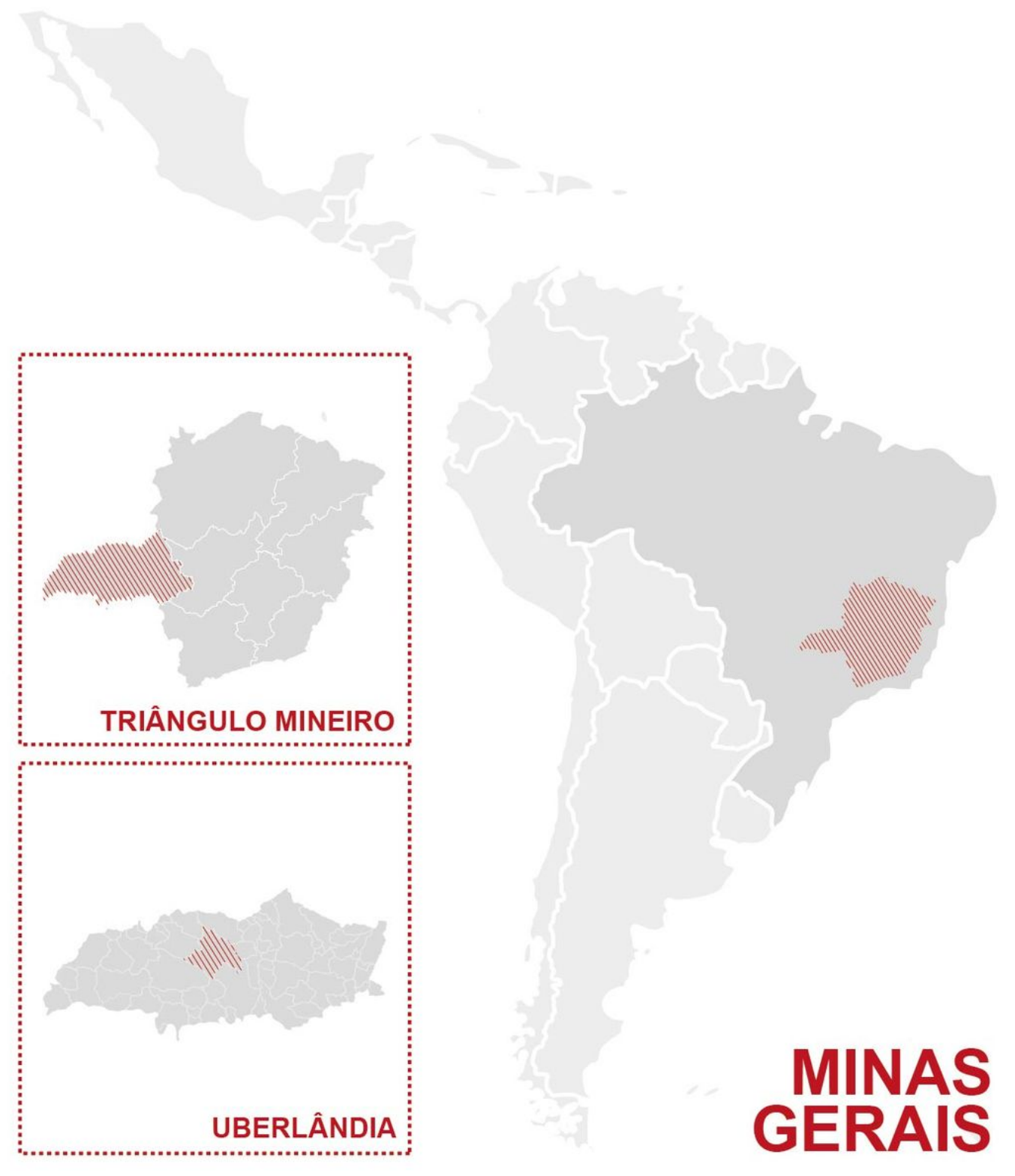

Figure 1

Uberlândia's location according to the Triângulo Mineiro Region and Minas Gerais State. Unspecified scale. Source: Authors 


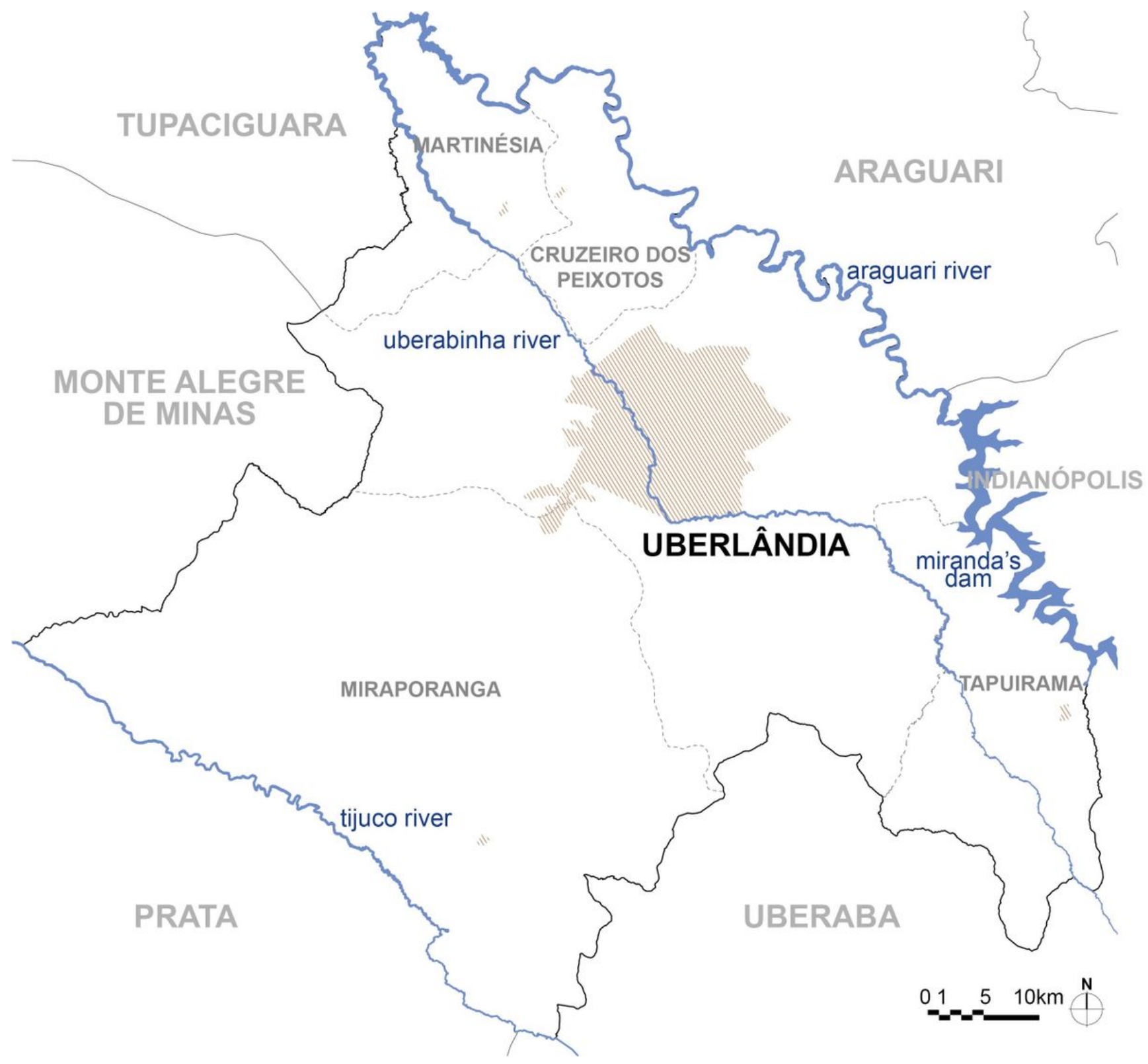

Figure 2

Map of Uberlândia (city and its districts) with neighbouring cities. Unspecified scale. Source: Cartography provided by Municipality of Uberlândia, in 2018, with authors' adaptations 


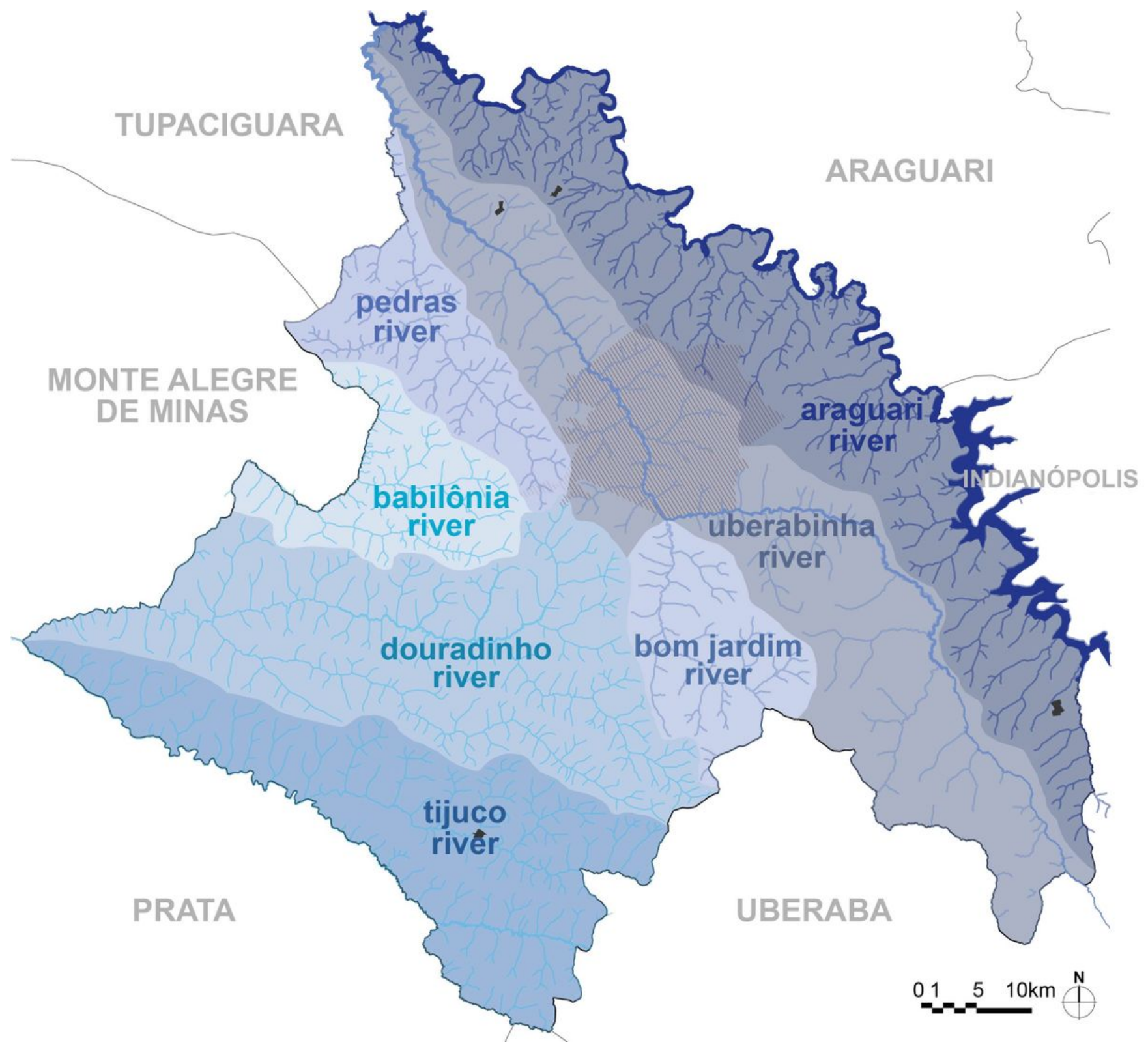

Figure 3

Map of drainage sub-basins of Uberlândia. Unspecified scale. Source: Cartography provided by Municipality of Uberlândia, in 2018, with authors' adaptations 


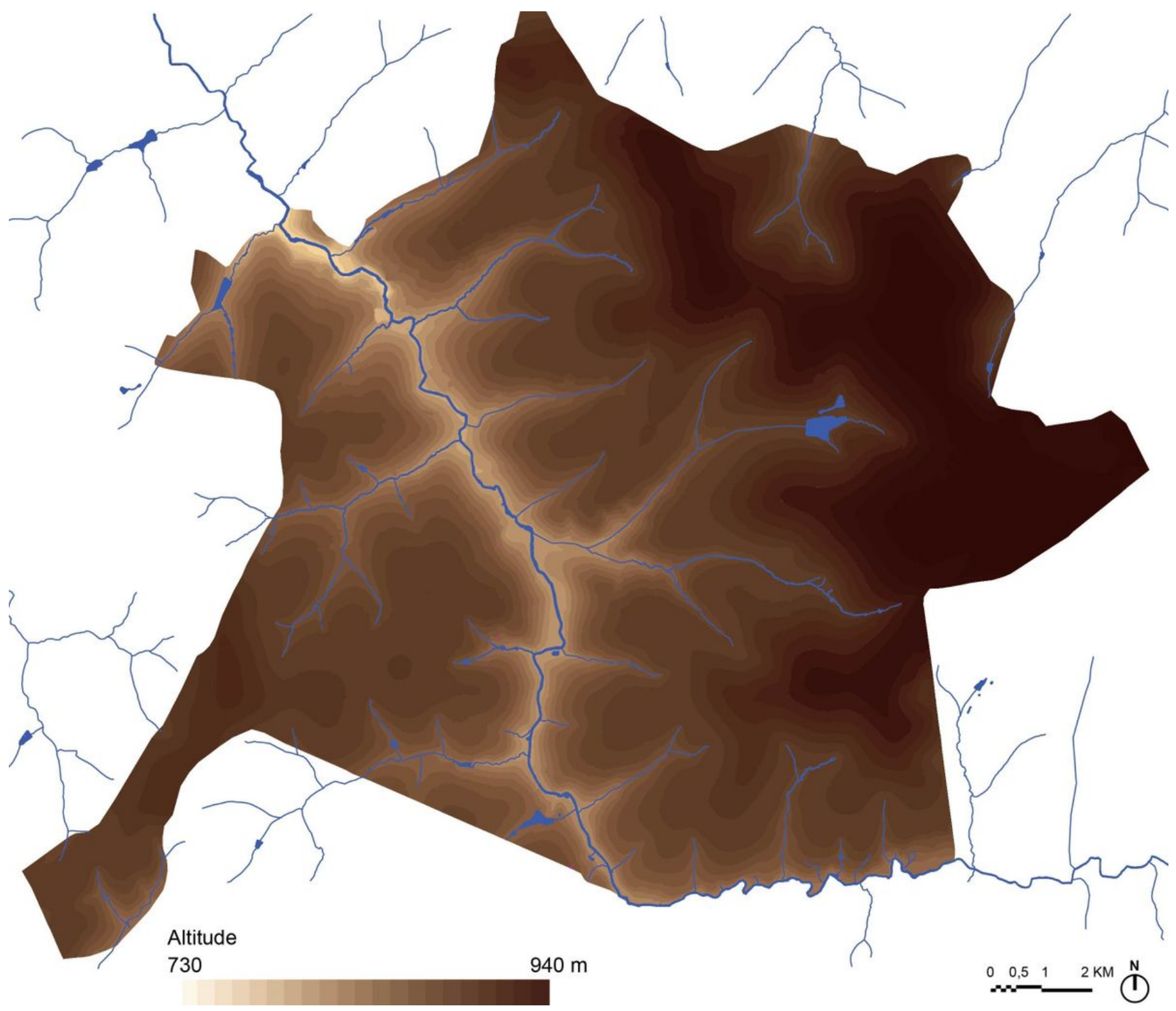

Figure 4

Map of the topography of Uberlândia. Unspecified scale. Source: Cartography provided by Municipality of Uberlândia, in 2018, with authors' adaptations 


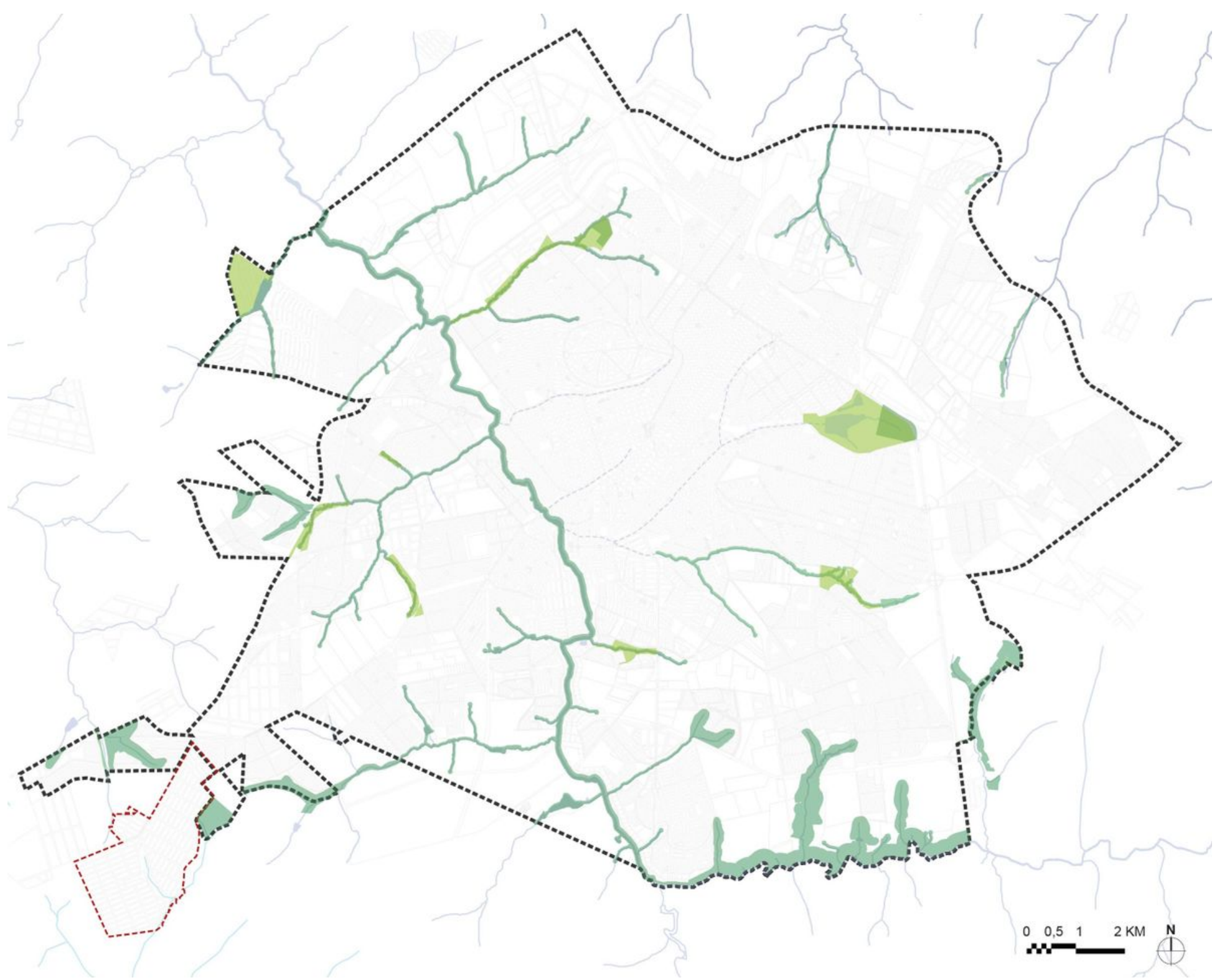

Figure 5

Map of open spaces in Uberlândia. Unspecified scale. Source: Cartography provided by Municipality of Uberlândia, in 2018, with authors' adaptations 


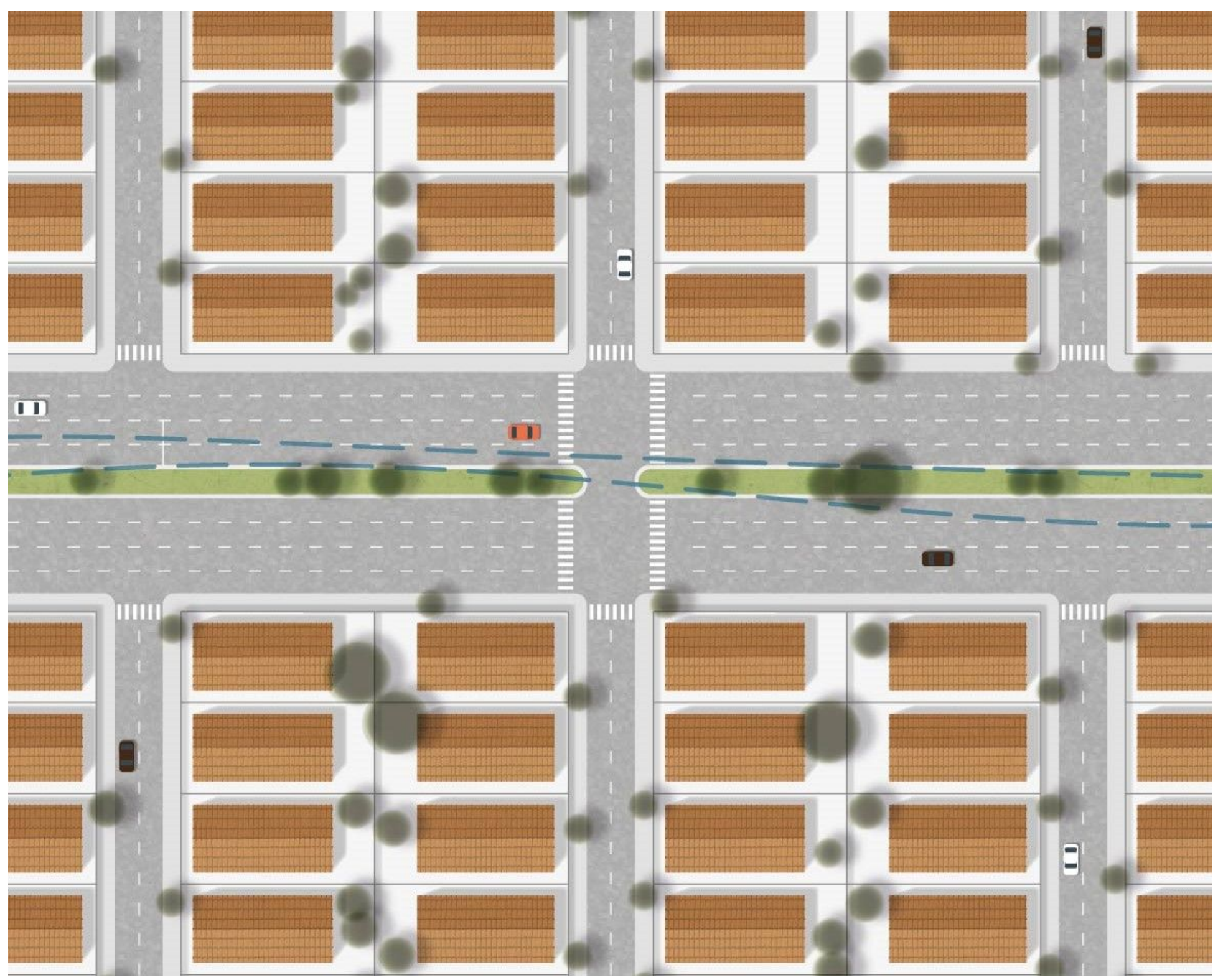

Figure 6

Schematic plan of pattern 01. Unspecified scale. Source: Authors 


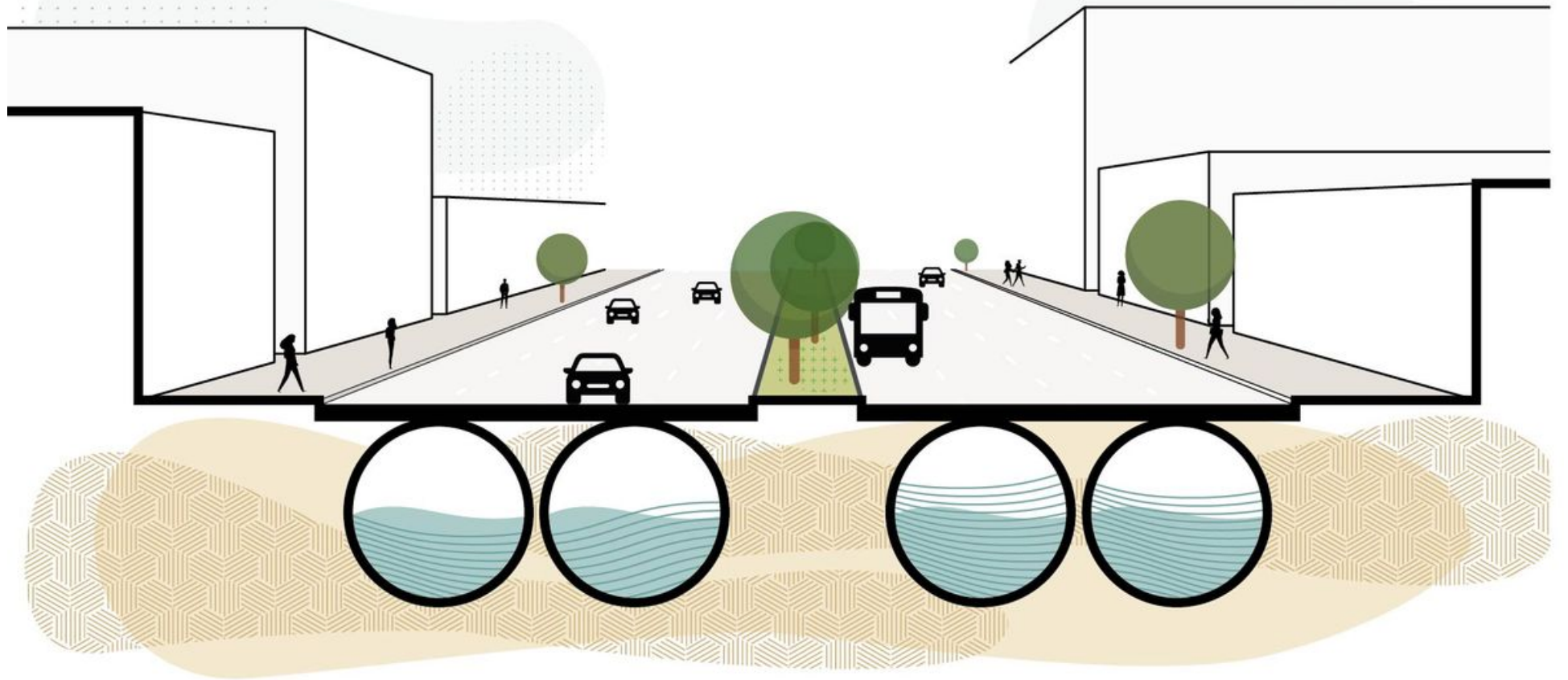

Figure 7

Section with a perspective of pattern 01. Unspecified scale. Source: Authors 


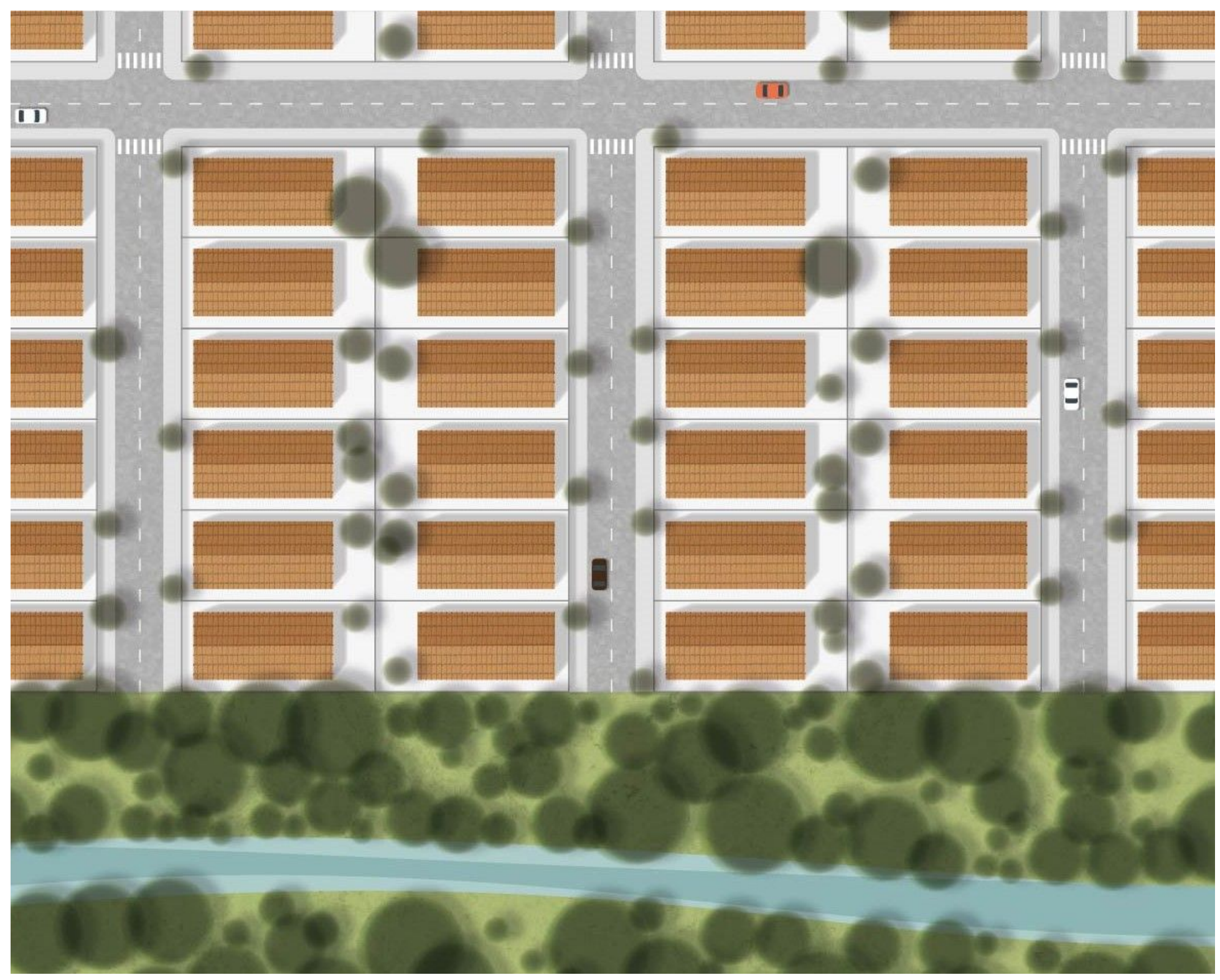

\section{Figure 8}

Schematic plan of pattern 02. Unspecified scale. Source: Authors 


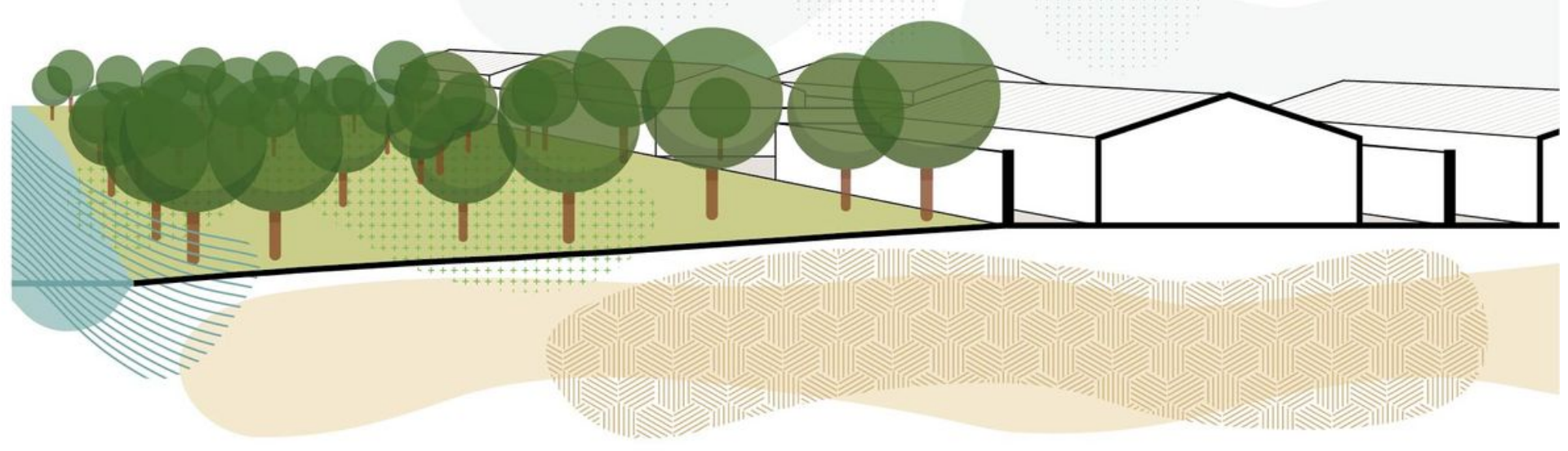

Figure 9

Section with a perspective of pattern 02. Unspecified scale. Source: Authors 


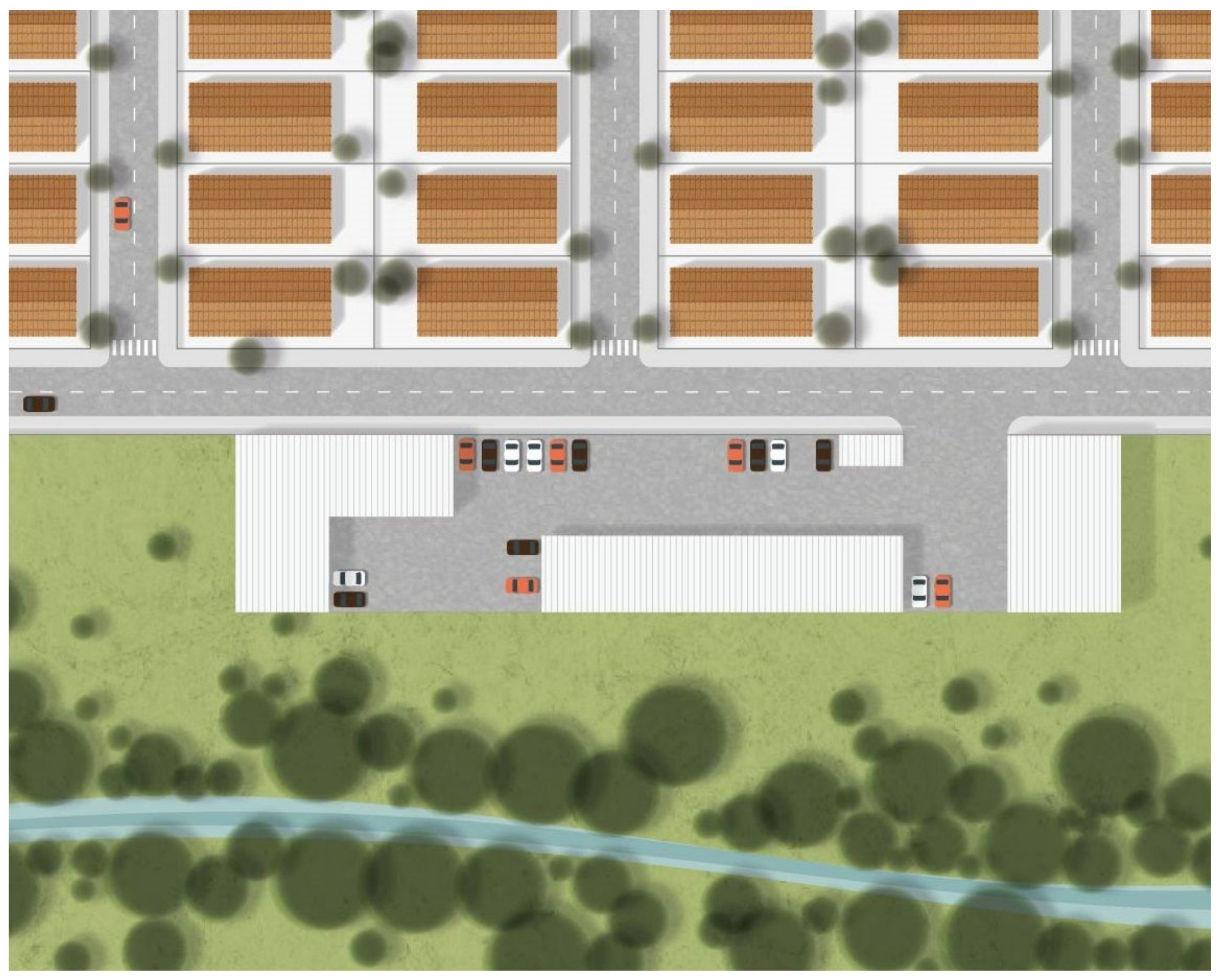

Figure 10

Schematic plan of pattern 03. Unspecified scale. Source: Authors 


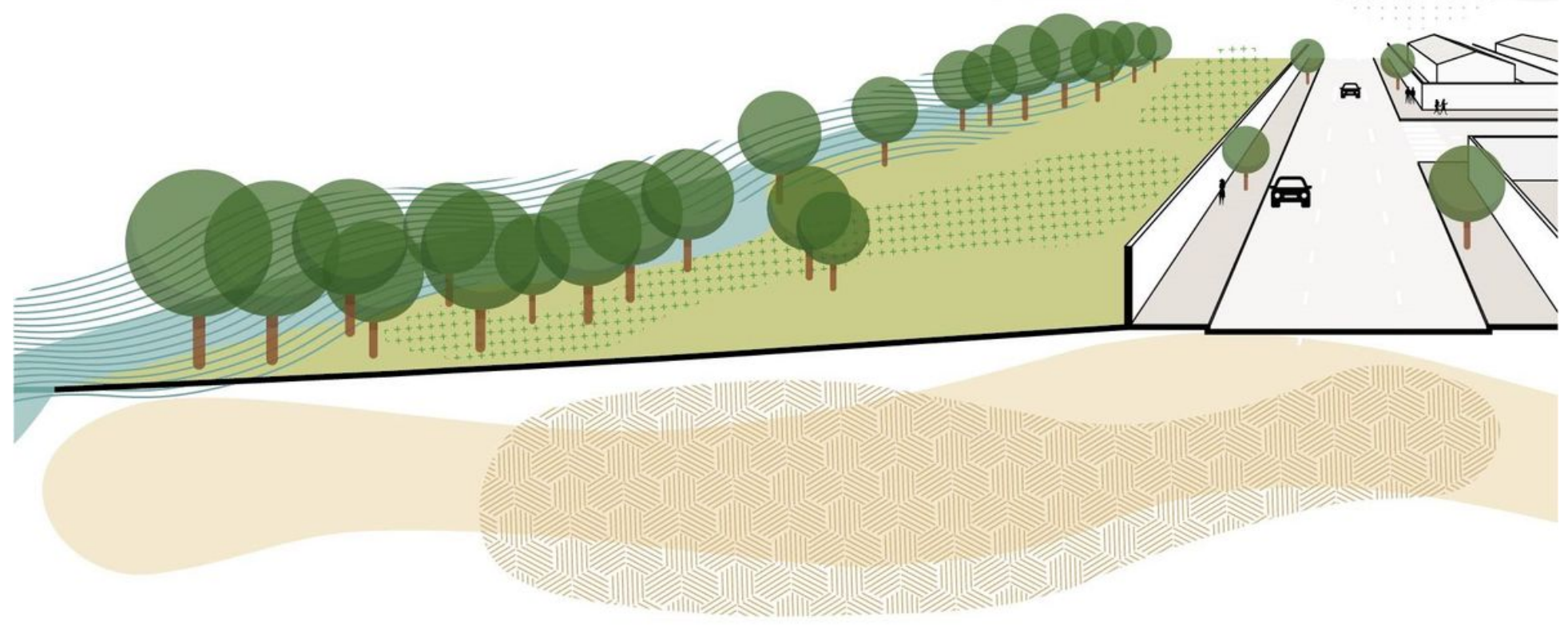

Figure 11

Section with a perspective of pattern 03. Unspecified scale. Source: Authors 


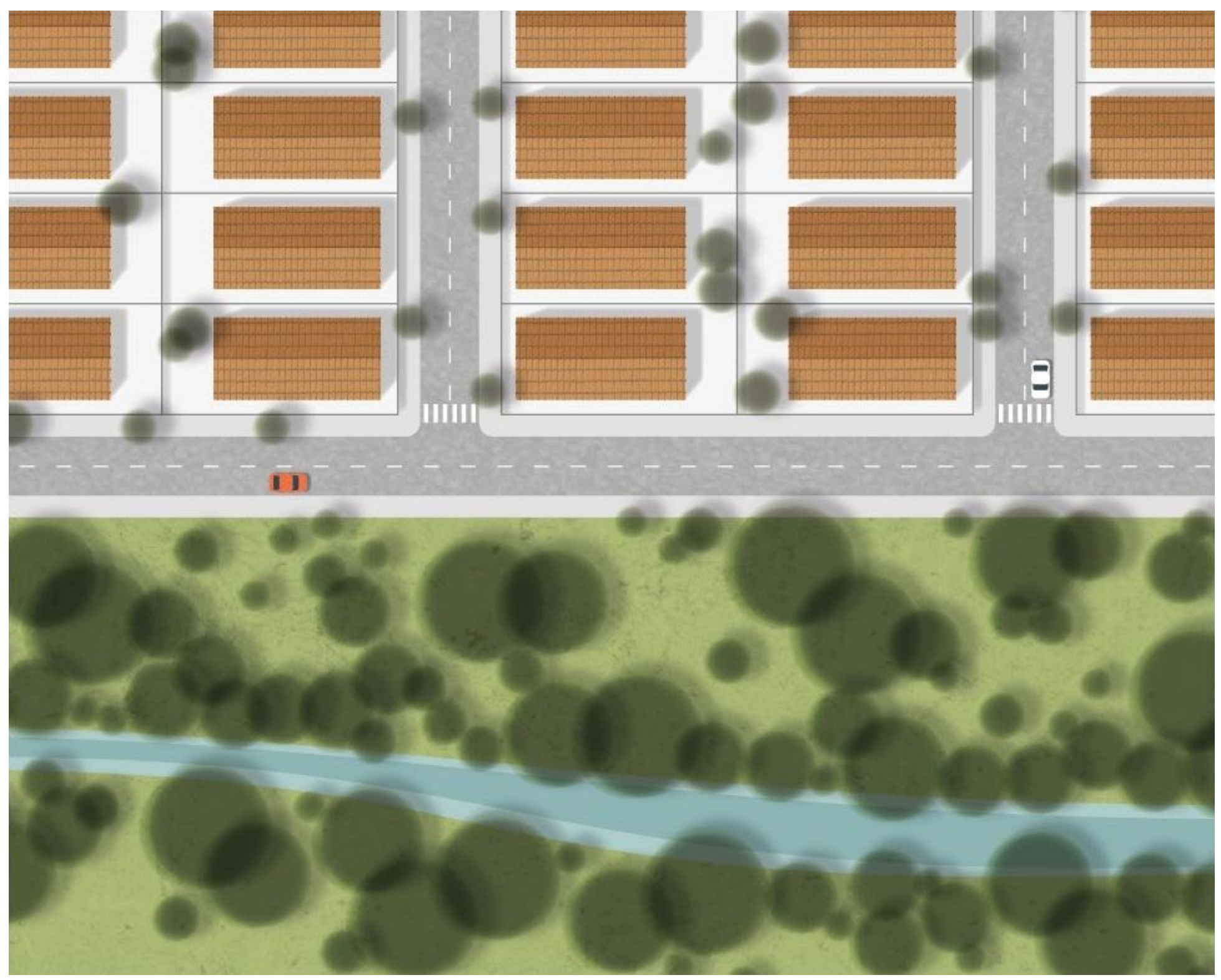

\section{Figure 12}

Schematic plan of pattern 04 . Unspecified scale. Source: Authors 


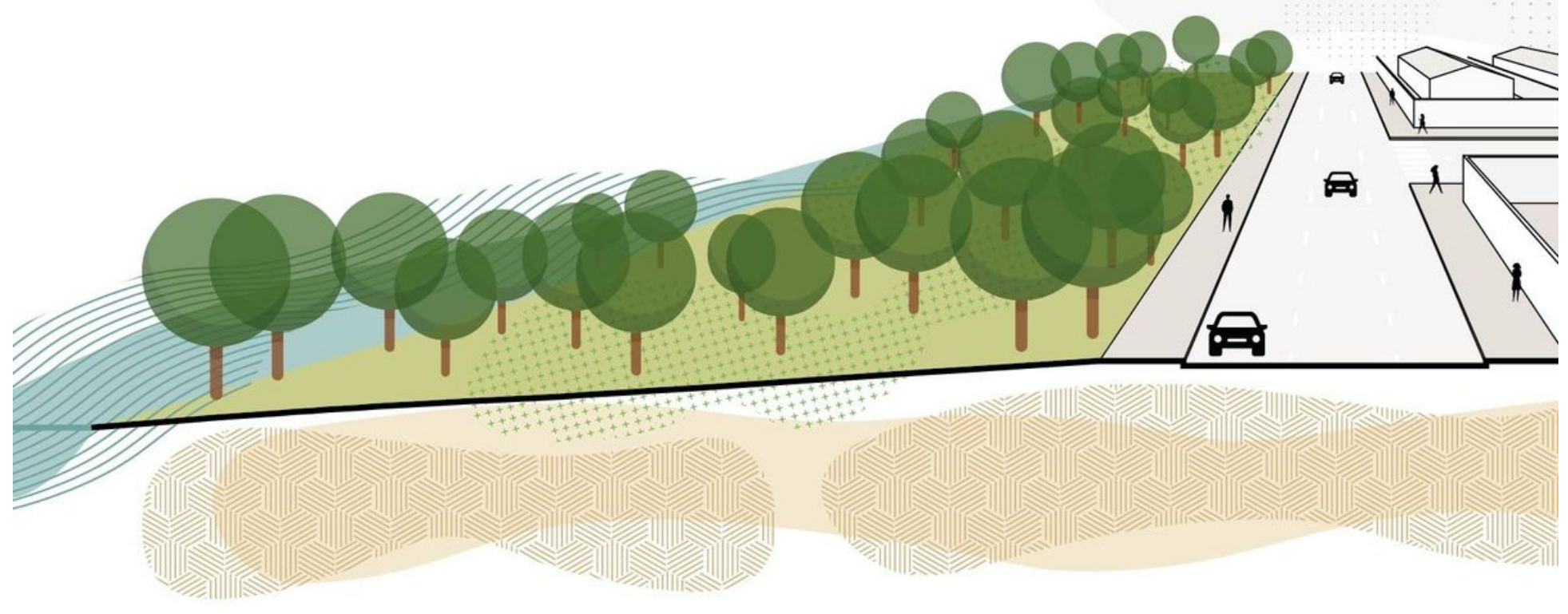

Figure 13

Section with a perspective of pattern 04 . Unspecified scale. Source: Authors 


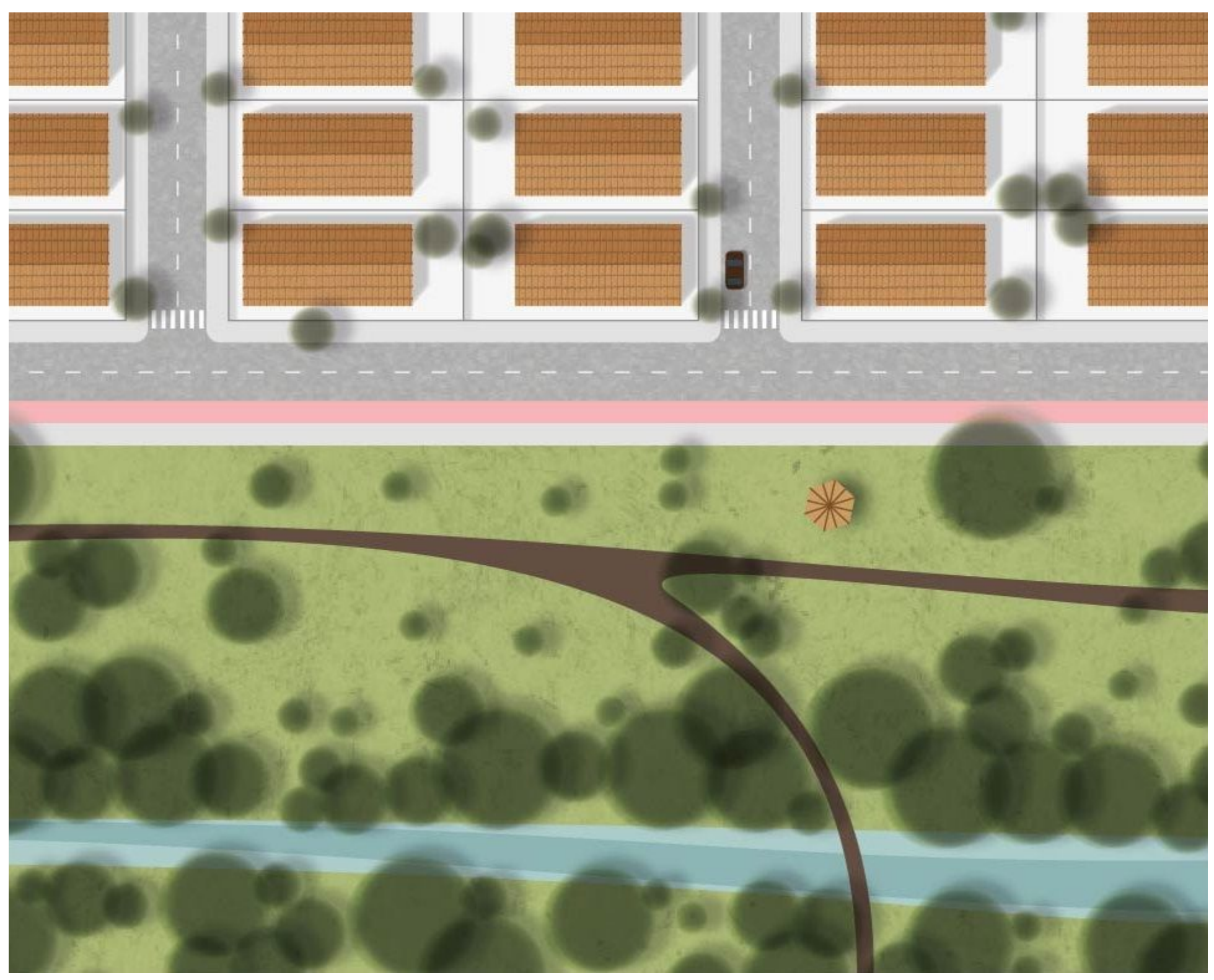

Figure 14

Schematic plan of pattern 05 . Unspecified scale. Source: Authors 


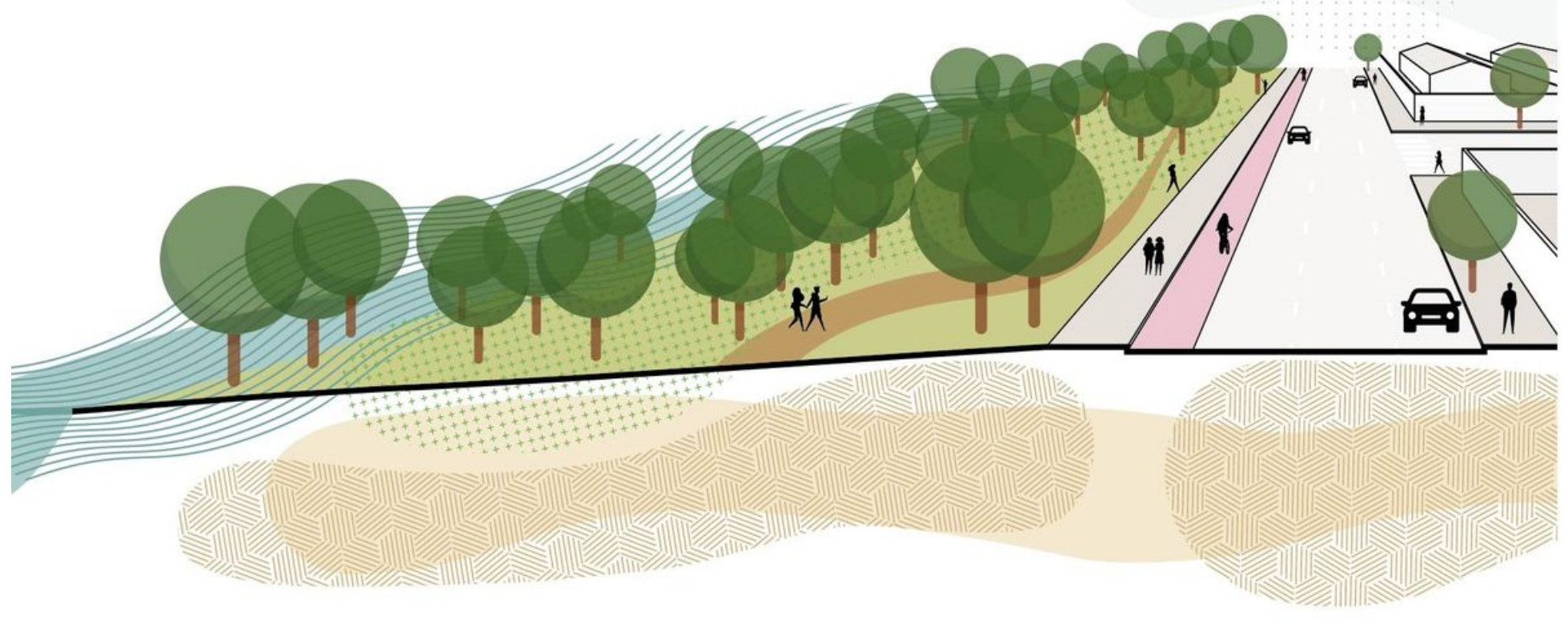

Figure 15

Section with a perspective of pattern 05. Unspecified scale. Source: Authors 

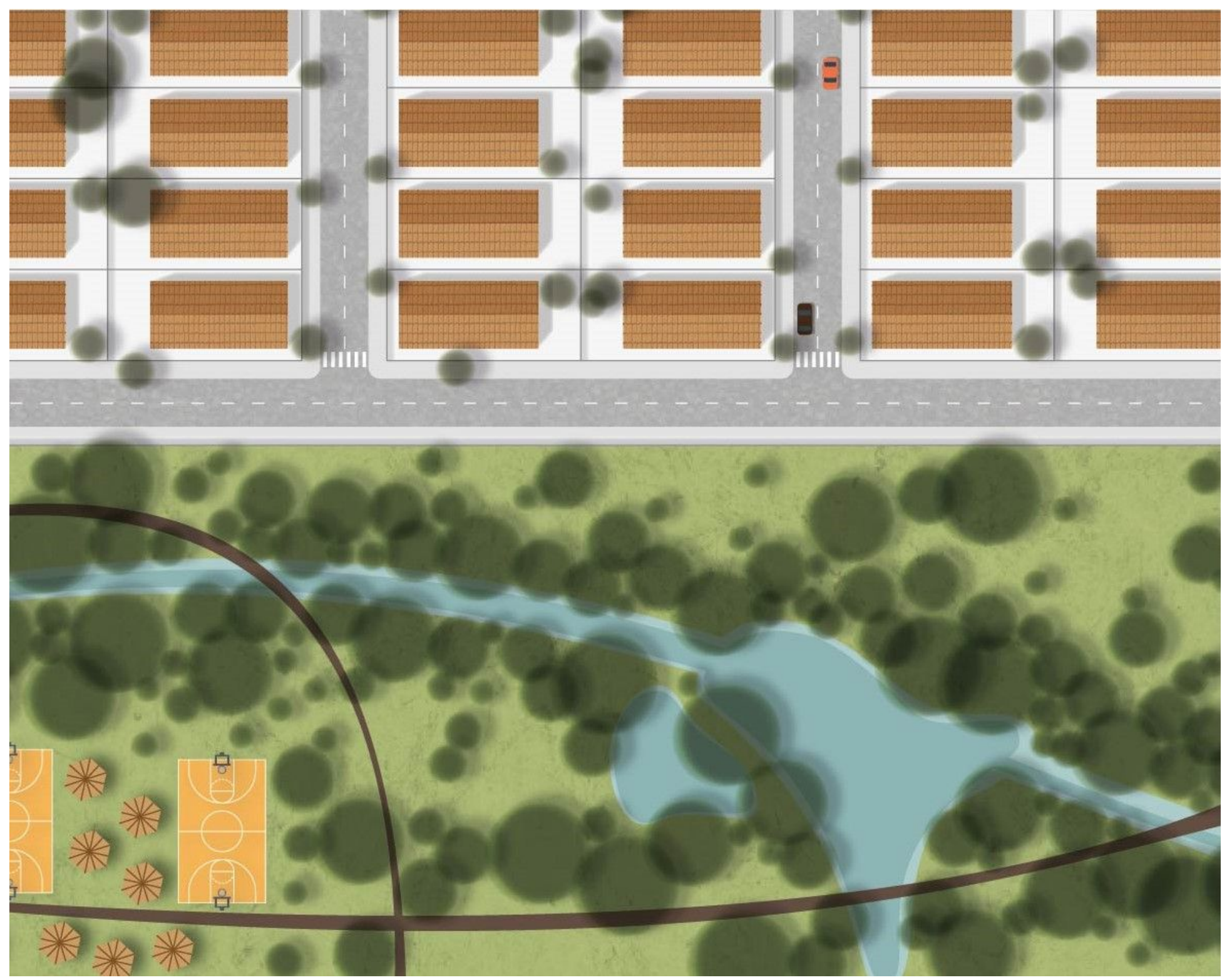

\section{Figure 16}

Schematic plan of pattern 06. Unspecified scale. Source: Authors 


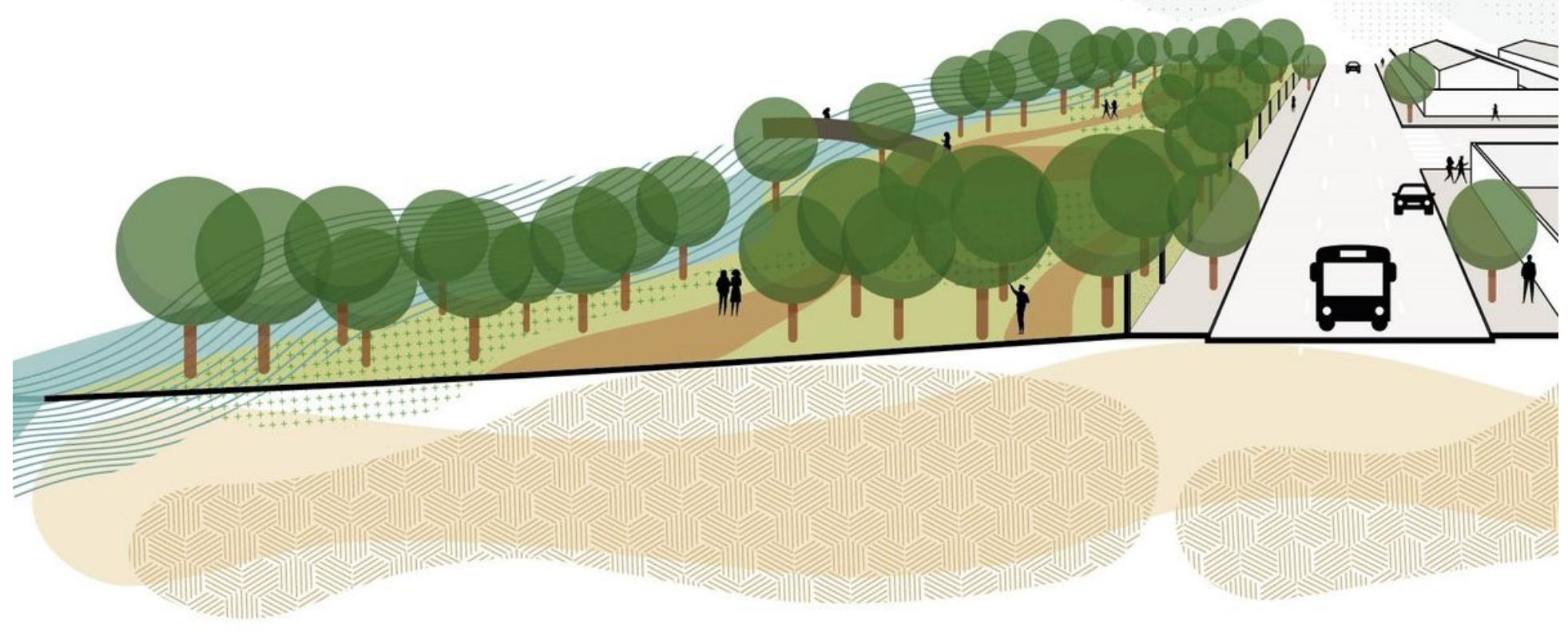

Figure 17

Section with a perspective of pattern 06. Unspecified scale. Source: Authors 


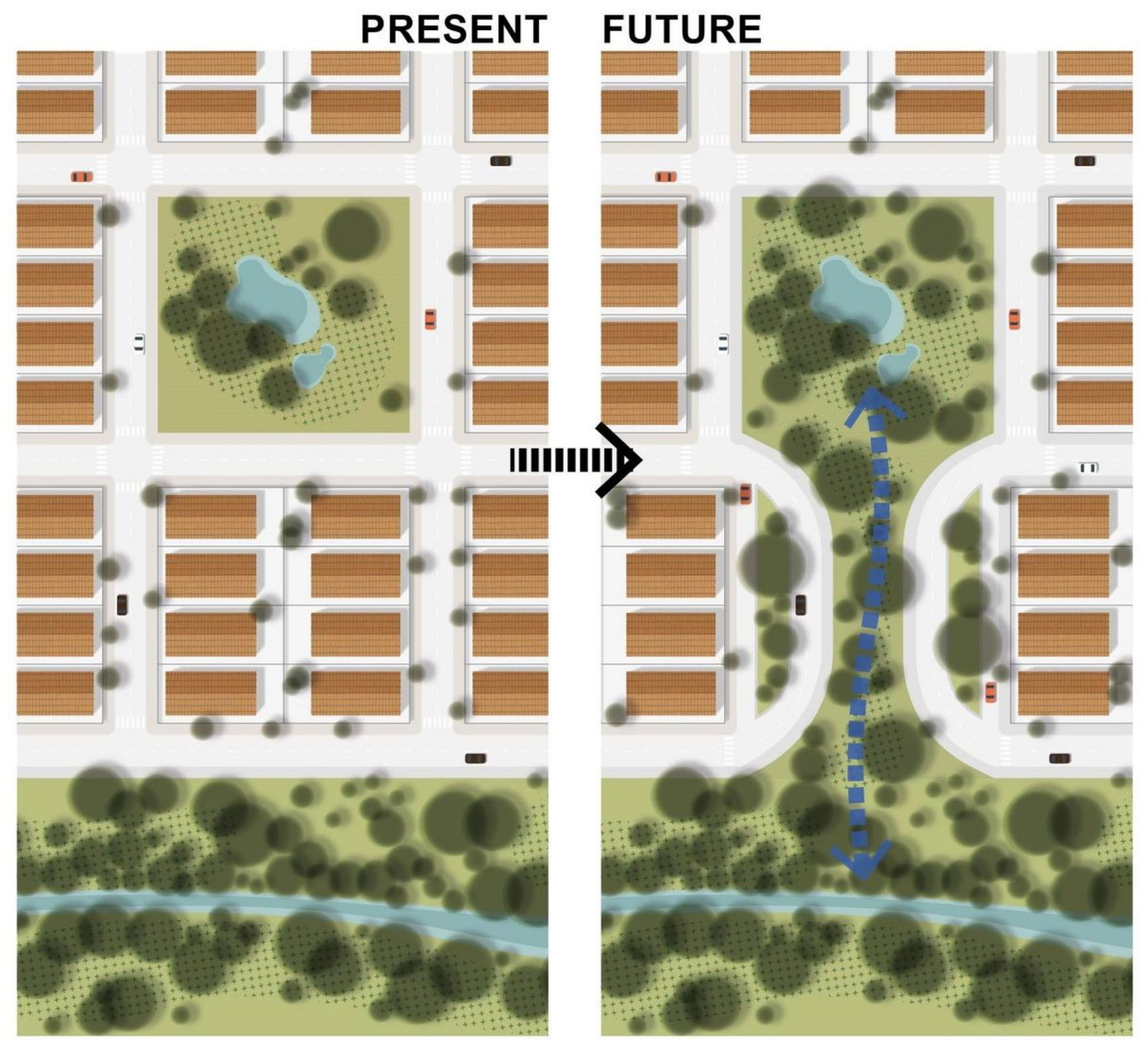

\section{Figure 18}

Example of future urban design for demarcating, connecting two APPs with an additional green area. Source: Authors 


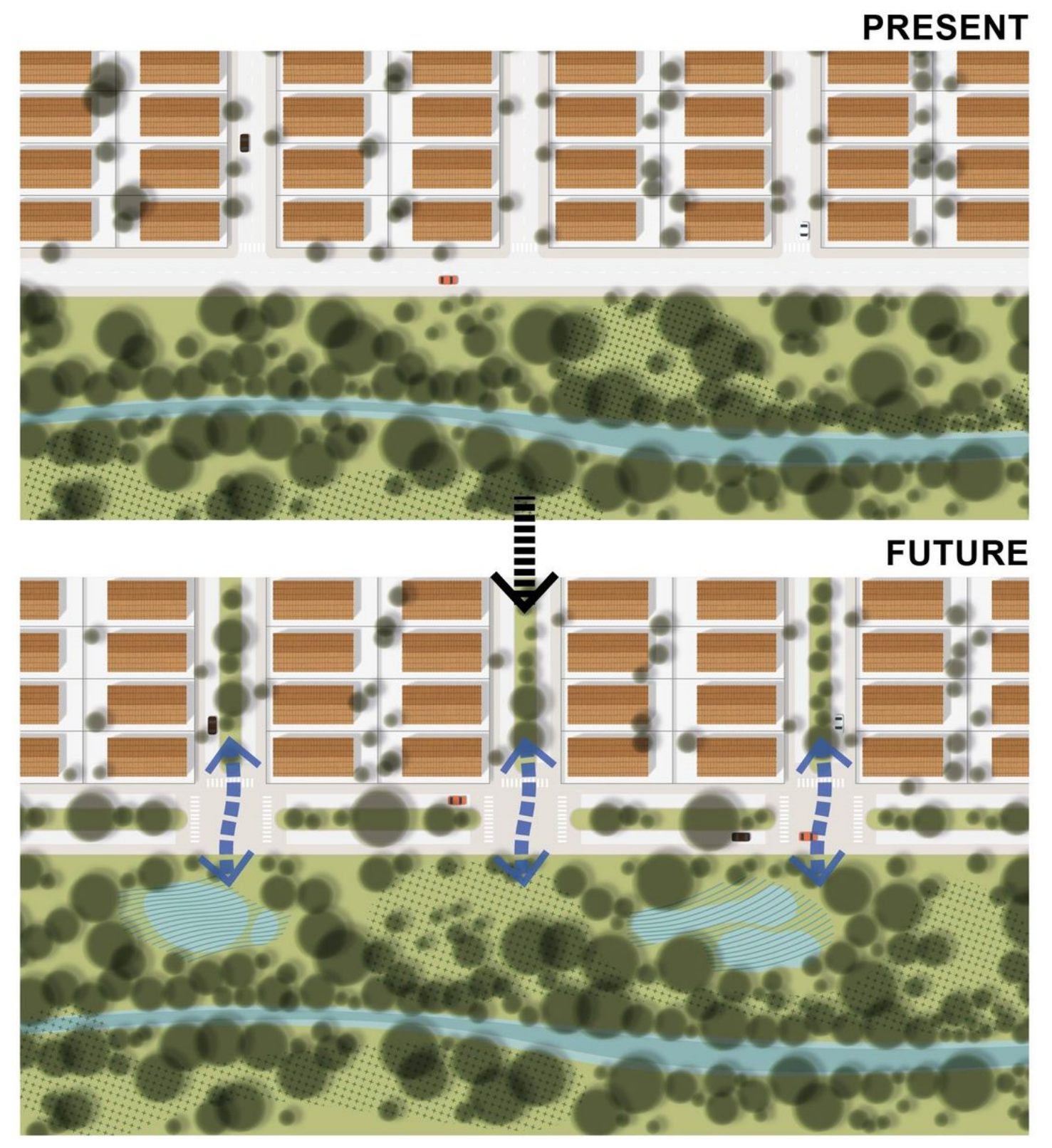

\section{Figure 19}

Example of future urban design for buffering, with the implementation of transition areas. Source: Authors 


\section{FUTURE}

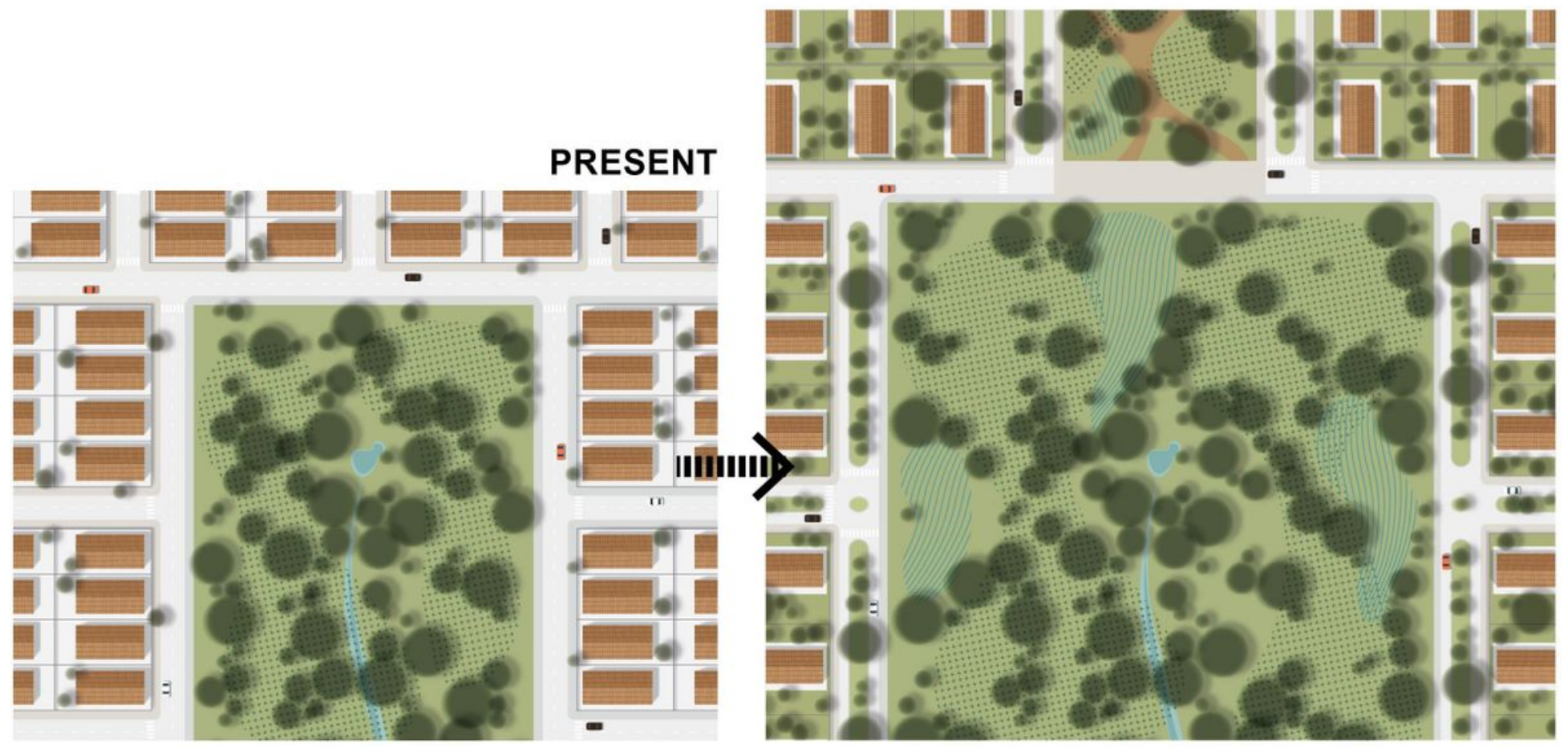

\section{Figure 20}

Example of future urban design for concentrating, creating transition zones of lower density rate around springs. Source: Authors 


\section{PRESENT}

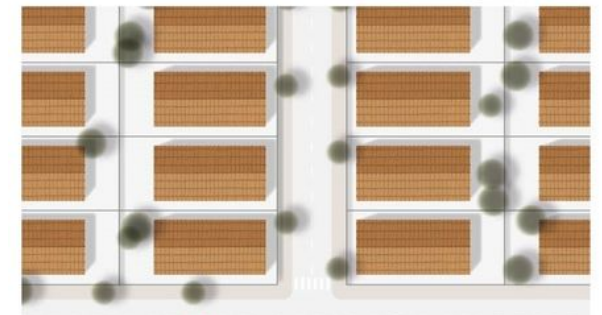

(1)
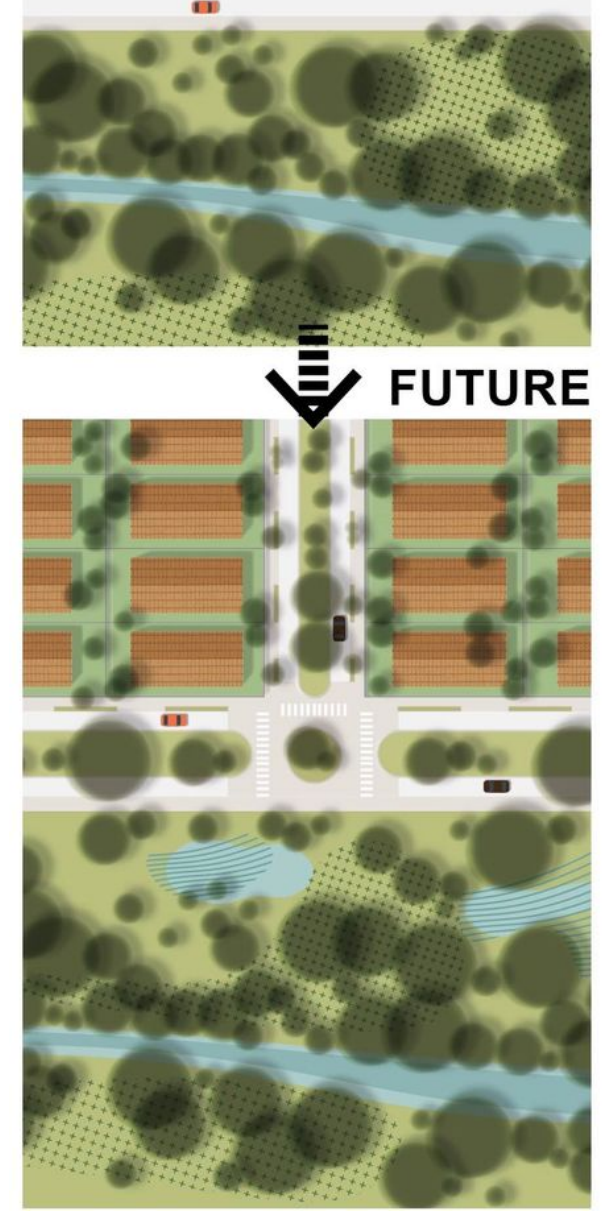

\section{Figure 21}

Example of future urban design for assimilating, with created urban natures. Source: Authors 